\title{
In Vitro Breeding Techniques
}

\author{
held at the \\ 88th ASHS Annual Meeting \\ University Park, Pa. \\ 23 July 1991
}

\begin{abstract}
sponsored by the
Plant Biotechnology Working Group

Fruit Breeding Working Group

Ornamental Plant Breeding Working Group

Vegetable Breeding Working Group
\end{abstract}

published by the American Society for Horticultural Science Alexandria, VA 22314-2824

as a special insert in

HortScience 29(11), Nov. 1994 


\title{
Workshop Papers and Authors
}

\section{Presiding: Mark P. Bridgen}

Sources and Frequency of Somaclonal Variation

Robert M. Skirvin, Kenneth D. McPheeters, and Margaret Norton

Development of New Cultivars via Anther Culture

Richard E. Veilleux

\author{
Observations and Suggestions for Improving Somatic Hybridization by Plant Protoplast Isolation, \\ Fusion, and Culture \\ Jude W. Grosser
}

\author{
A Review of Plant Embryo Culture \\ Mark P. Bridgen
}

\section{Sources and Frequency of Somaclonal Variation}

\author{
Robert M. Skirvin, Kenneth D. McPheeters, and Margaret Norton \\ Department of Horticulture, University of Illinois, 258 Plant and Animal Biotechnology Building, 1201 West \\ Gregory Drive, Urbana, IL 61801
}

Plant tissue culture was introduced to the public as an asexual method to propagate plants rapidly and reliably. Many ornamental, fruit, and vegetable crops are now routinely propagated commercially in vitro. The ease of tissue culture propagation has revitalized certain ornamental industries and facilitated the rapid introduction of new cultivars. In spite of new cultivars and in spite of these successes, some commercial propagators are now advertising that their plants are "not from tissue culture," while others continue to advertise that their plants are tissue culture-derived (e.g., American Nurseryman, Apr. 1990, Classified Section, "Daylilies").

What is going on? Commercial nurseries are now encountering the ubiquitous phenomenon of somaclonal (tissue culture-derived) variation (Anonymous, 1989; Knuttel, 1989). Since all cells of an organism are derived from a single cell, researchers assumed that plants derived from cells of a mother plant would yield plants identical to the mother plant. However, according to Scowcroft (1985), who has researched somaclonal variation since it was formally acknowledged, "clonal uniformity is now recognized as the exception rather than the rule."

\section{WHAT IS SOMACLONAL VARIATION?}

Somaclonal variation is variation among regenerated plants that occurs as a result of tissue culture of any type. It may arise from preexisting or induced variation. Some scientists add another aspect to the definition and require that somaclonal variation be heritable through a sexual cycle. Unfortunately, it is not always possible or feasible to demonstrate heritability because of complex sexual incompatibilities, seedlessness, polyploidy, or long generation times. Hence, it may be difficult or impossible to verify the heritable nature of somaclonal variation for these crops.

Such variation is a serious problem confronting researchers or propagators who require uniformity. However, the natural variability associated with tissue culture represents a pool upon which selection pressure can be imposed to isolate unique forms of a clone. The amount

The cost of publishing this paper was defrayed in part by the payment of page charges. Under postal regulations, this paper therefore must be hereby marked advertisement solely to indicate this fact. of variation that can be expected will vary with the clone, age of the culture, use of mutagenic agents, and selection pressure applied to cell suspensions or callus cultures of clones for stress conditions such as salt level, herbicides, microorganisms or their byproducts, and specific metabolites (Skirvin, 1978). The exploitation of such natural and induced variation seems especially applicable to old woody plant cultivars, such as 'Bartlett' pear (Pyrus communis L.) and 'Delicious' apple (Malus domestica Borkh.) (introduced in 1770 and 1893, respectively) (Skirvin, 1977), which could be expected to have accumulated many mutant cells that may have stabilized into chimeras of various complexity.

Skirvin and Janick (1976a) were among the first to emphasize the importance of clonal variation in genotype improvement of horticultural species. Shepard et al. (1980) demonstrated extensive variability among plants regenerated from cultured leaf protoplasts (protoclones) of 'Russet Burbank' potato (Solanum tuberosum L.). In investigating the extent and possible significance of this source of genetic variability, Larkin and Scowcroft (1981), who have reviewed the topic extensively, first suggested that the term "somaclonal variation" be used to describe the phenotypic variation observed among plants regenerated after a passage through tissue or cell culture. Tissue culture-related variants have also been referred to as calliclones (Skirvin and Janick, 1976a), phenovariants (Sibi, 1976), and protoclones (Shepard et al., 1980). However, the term somaclonal variation describes the system best and has justifiably become the standard term to describe the phenomenon.

The amount of variation that can be encountered in vitro has been described for banana (Musa xparadisi L.) by Smith and Drew (1990) in a review of Australian tissue culture programs and prospects. They reported that up to $90 \%$ of the in vitro-derived banana plants in Australia were off-types under field conditions. The off-types primarily consisted of dwarf "choke-throat" plants. This choke-throat condition prevents the bunch from emerging from the banana shoot and produces closely packed, undersized fruit. Although the choke-throat off-types were devastating to the banana tissue culture industry (Walduck et al., 1988), as reported by Smith and Drew (1990), a few dwarf plants with normal fruiting characteristics have been observed (Smith and Hamill, 1991). According to Smith and Drew (1990), 
banana breeders in Australia have used conventional breeding protocols with this triploid parthenocarpic fruit crop for more than 60 years and isolated no commercially acceptable cultivars. They hope that new phenotypes will be selected among the banana somaclones and eventually introduced as cultivars.

Somaclonal variation is observed in all crops; some commercial tissue culture companies maintain greenhouse space for conserving and growing out off-types in an effort to obtain marketable plants (Michael Kane, Univ. of Florida, Gainesville, personal communication).

Somaclonal variation is not limited to the plant kingdom. There have been hundreds of reports of cell line variants among animal tissue cultures. In fact, the phenomenon of somatic variation was so well known in animal systems that an entire book was devoted to the topic in 1964 (Harris) - long before the topic was discussed in plant systems.

\section{TYPES OF SOMACLONAL VARIATION}

Somaclonal variation appears to result from both pre-existing genetic variation within the explants and variation induced during the tissue culture phase (Evans et al., 1984). There appear to be two types of somaclonal variation: heritable and epigenetic. Heritable variation is stable through the sexual cycle or repeated asexual propagation; epigenetic variation may be unstable even when asexually propagated. Somaclonal variation can involve either single or multiple genes and can be due to alterations in DNA bases, genes, chromosomes, or entire sets of chromosomes (Orton, 1984).

Epigenetic variation is also known as developmental variation. It includes persistent changes in phenotype that involve the expression of particular genes (e.g., the gene for thorniness of juvenile Citrus) (Hartmann and Kester, 1983). Explants from mature parents adapt to the in vitro environment by becoming more juvenile in a step-wise manner. Tissue cultures may be at any stage of development, from mature to fully juvenile. Plants regenerated from such tissues will vary, depending on the developmental stage that the tissue had attained when the stimulus to regenerate was received. Shoot regeneration from dedifferentiated cultures can yield an immature form of the parental clone that may or may not be stable over time. For instance, Eucalyptus cultures could yield regenerants with sessile leaves, a juvenile trait. However, with time, such juvenile traits cease to be expressed and the parental type reappears.

The best known example of epigenetic variation is the loss of auxin, cytokinin, or vitamin requirements by callus (Jackson and Lyndon, 1990; Meins, 1982; Skirvin, 1978). These changes in requirements are collectively known as tissue or cellular habituation. Other epigenetic changes include extreme vigor ex vitro (Swartz et al., 1981) that is probably associated either with the reversion to juvenility discussed earlier or with virus elimination (Abo El-Nil and Hildebrandt, 1971). Tissue culture-derived plants behave like seedlings and grow vigorously until flowering has been induced. At that time, the plant often reverts to the phenotype of the parental plant. This temporary sort of vigor has been exploited by the tissue culture industry to produce vigorous young plants that transplant easily, grow rapidly, and become established more quickly than conventionally propagated plants (Swartz et al., 1981). Transient dwarfism is probably epigenetic also and may be due to a carryover of growth regulators from the tissue culture medium. Many dwarfed plants revert to a normal growth habit after a season or two of growth under field or greenhouse conditions (McPheeters and Skirvin, 1989; Moore et al., 1991).

An example of heritable somaclonal variation is the development of pure thornless blackberries from chimeral parents. 'Thornless Evergreen' (TE) is a thornless mutant of the European thorny apomictic 'Evergreen' blackberry (Rubus laciniatus Willd.) (Darrow, 1931; Waldo, 1977). TE is a periclinal ("hand-in-glove") chimera in which a layer of mutant (thornless) cells surrounds a core of wild-type (thorny) tissue. TE blackberry is grown widely in the Pacific northwestern United States and is one of the most economically important blackberry cultivars in the United States (Moore and Skirvin, 1990).

Although the TE plant appears completely thornless, its histological thornlessness is not stable since the plant produces thorny adven- titious root suckers. This instability is due to the fact that TE is a periclinal chimera with its histogenic layers arranged such that a layer of $\mathrm{L}_{\mathrm{I}}$-derived mutant thornless tissue overlies wild-type thorny tissue. Root cuttings of TE arise from $\mathrm{L}_{\mathrm{III}}$-derived internal tissue that has the thorny genotype and therefore "reverts" back to the thorny condition. In addition, gametes of TE that arise from the $\mathrm{L}_{\mathrm{II}}$-derived tissue express the thorny, not the thornless, character in crosses. The chimeral nature of TE is maintained commercially by layerage and cuttage (Darrow, 1931; McPheeters and Skirvin, 1983; Waldo, 1977). These asexual systems produce new plants from pre-existing axillary buds and thus maintain the chimeral status.

Rapidly proliferating TE shoot-tip cultures formed many shoots in vitro (McPheeters and Skirvin, 1983). Nearly half of the TE regenerants were dwarfed and had a unique bent petiole phenotype. Root segments from these dwarfed plants produced thornless sucker plants; roots of normal-sized vigorous plants produced thorny suckers. The pure thornless blackberries had probably developed as adventitious shoots from TE epidermal cells; the full-sized plants were still chimeras and of axillary bud origin. Because the dwarfed plants were pure thornless, their gametes were expected to carry the thornless character. When a sample of these pure thornless plants were hybridized and selfed, the bent petiole character was found to be linked to a dominant thornless gene $\left(S_{t e}\right)$ that was transmitted sexually (Hall et al., 1986a).

A sample of 150 pure thornless TE plants was moved to a field where they exhibited continuous somaclonal variation for plant vigor, height, erectness, leaf morphology, fertility, and flower and prickle number (McPheeters and Skirvin, 1989). Among the somaclones, a pure thornless and fully fertile form of TE has been selected. This unique plant is slightly smaller than the parent plant and produces thornless, not thorny, adventitious root suckers. The somaclone has been tested for its commercial potential in Oregon for several years (L. Martin, Dept. of Horticulture, Arkansas State Univ., personal communication). It produces fruit that appears identical to that of the parent type. The clone is now being patented and will soon be formally introduced as a new cultivar. A similar dominant thornless gene has been identified from 'Thornless Loganberry' (Hall et al., 1986b) and named $S_{f l}$ (Rosati et al., 1986). The pure thornless type was released to the public as 'Lincoln Logan' (Hall et al., 1986c).

\section{VALUE OF SOMACLONAL VARIATION FOR PLANT IMPROVEMENT}

To have an impact on a plant breeding program, an in vitro scheme must either produce a plant useful for breeding or be useful directly. A few somaclones have been released as named cultivars (Table 1), but many somaclones are still being tested. Ostry and Skilling (1987), for instance, screened poplar regenerants with Septoria musiva and isolated stable putative somaclones with resistance to this fungus. They pointed out that these plants should not be considered heritable somaclones until genetic analyses had demonstrated it. However, in an economically valuable asexually propagated crop such as poplar (Populus L.), even a stable epigenetic change of an elite poplar could be of value. Furthermore, Ostry and Skilling state that "somatic variation may be a better means of tree improvement than either direct

Table 1. A sample of named horticultural cultivars derived from tissue culture via somaclonal variation.

\begin{tabular}{|c|c|}
\hline Crop & Source \\
\hline \multicolumn{2}{|l|}{ Ornamental } \\
\hline Eustoma grandiflorum & $\begin{array}{l}\text { Griesbach and Semeniuk, 1987; } \\
\text { Griesbach et al., } 1988\end{array}$ \\
\hline Hemerocallis Yellow Tinkerbell & Griesbach, 1989 \\
\hline \multicolumn{2}{|l|}{ Paulownia tomentosa } \\
\hline Somaclonal Snowstorm & Marcotrigiano and Jagannathan, 1988 \\
\hline Pelargonium Velvet Rose & Skirvin and Janick, $1976 \mathrm{~b}$ \\
\hline Torenia UConn White & Brand and Bridgen, 1989 \\
\hline \multicolumn{2}{|l|}{ Fruit } \\
\hline Rubus Lincoln Logan & Hall et al., 1986b, 1986c \\
\hline \multicolumn{2}{|l|}{ Vegetable } \\
\hline Apium UC-T3 Somaclone & Heath-Pagliuso et al., 1989 \\
\hline Ipomoea batatas Scarlet & Moyer and Collins, 1983 \\
\hline
\end{tabular}


gene insertion or Agrobacterium-mediated transformation because of the many [regulatory and] technical difficulties that must be overcome with those methods."

The power of somaclonal variation for plant improvement is that new traits are developed in the best cultivars available. Most scientists perform somaclonal variation research with elite individuals or clones with known potential as cultivars or breeding lines. The variation observed in such material can result from various sources (discussed below), including the induction of expression by genes that are present in the genome but that had been suppressed at some stage of development. However, one should be wary of assuming that characters propagated through repeated asexual generations are stable. For instance, Maretzki (1987) isolated a somaclone of sugarcane (Saccharum officinarum L.) with resistance to eye-spot. The character proved to be stable through 10 years of asexual propagation, but the trait was recently lost (Smith and Drew, 1990), which suggests either the epigenetic nature of resistance or a resistant strain of the fungus.

\section{ORIGIN OF SOMACLONAL VARIATION}

The causes of somaclonal variation are not well understood and have not been elucidated. However, among the heritable types of variation, single base-pair changes, chromosome deletions, translocations, and changes in ploidy have been encountered (D'Amato, 1991; Evans and Sharp, 1986). Variation is not limited to nuclear genes; Gengenbach and Umbeck (1982) have used restriction enzyme analysis of isolated mitochondrial DNA to demonstrate variation in mitochondrially controlled male sterility. The broad spectrum of variation available through both nuclear and cytoplasmic characters suggests that all classes of variation could be recovered and used for crop improvement.

\section{Pre-existing variation}

Multicellular explants. Explants derived from a single clone, seed, or seedling are assumed to be genetically uniform, permitting the conclusion that spontaneous genetic instability occurs in vitro (Orton, 1983). However, this assumption is not always valid, because explants may include several types of cells, such as phloem, parenchyma, cortex, and xylem parenchyma. These cells may also vary in their ploidy level. To account for the lack of uniformity in multicellular explants, Bright et al. (1983) suggested that explants derived from sources other than protoplasts be called "complex cultures" in recognition of their multicellular origin.

Chimeras. Many plants are known to be chimeras. They consist of cell sectors or tissues that differ in genetic constitution and that have developed from a meristem containing layers or sectors of mutated tissue (Hartmann and Kester, 1983). Dermen (1960) has described many chimeras, and Whitham et al. (1984) wrote a fascinating discussion of the evolutionary value of chimera formation and maintenance in woody plants.

The arrangement of the genetically different tissues within the plant meristem affects chimera stability. The most stable chimera is the periclinal chimera. However, even these chimeras can exhibit instability by cell displacement and replacement (Stewart and Dermen, 1970), resulting in natural variation known as sports. Chimeral plants grown in tissue culture can yield variants in high percentages. For instance, as discussed earlier, McPheeters and Skirvin (1983) found that nearly half of the shoots obtained from tissue culture of a chimeral thornless blackberry were dwarfed and pure thornless. Much of the variation was attributed to chimeral segregation. Although some types of somaclonal variation can be explained in terms of chimeral segregation, regenerants may include somaclonal variants resulting from variation other than simple chimeral segregation. To test for preexistent somaclonal variation, regenerants may be subjected to another round of in vitro regeneration. Clones with pre-existent variation should yield more variability in the first generation than in the second, etc. After the second or third generation, one would expect that preexisting variation either would be eliminated or stabilized. Subsequent variation is more likely to be tissue culture derived.

The most common cause of chimeral dissociation is adventitious shoot production (Marcotrigiano, 1990). Adventitious shoots can be produced either in vivo or in vitro. Adventitious shoots usually arise from a single cell or a few cells that could be derived from a specific tissue (Broertjes, 1969; Broertjes and Keen, 1980). If adventitious shoots can be traced to a single cell, then any system that yields adventitious shoots can result in chimeral segregation. Adventitious shoot formation, the same process that results in chimeral segregation, also is related to the induction of somaclonal variation (Karp, 1989). It is well known that shoots of preformed origin (e.g., axillary buds) show much less variation than those that arise from adventitious budding systems, such as organogenesis or embryogenesis (Karp, 1989). Most of this variation is probably due to pre-existing variation or variation induced during callus formation, not the shoot formation process itself.

Conversely, clonal stability is best achieved by avoiding adventitious shoot formation (Karp, 1989; Skirvin, 1978). Therefore, in moderately proliferating, well-cared-for, shoot-tip cultures, one would expect little or no variation because propagules develop from axillary buds and thereby maintain the integrity of their histogenic layers. Such has been the case for nonchimeral blackberries. In fact, the use of commercial tissue culture proliferation techniques to propagate genetically thornless nonchimeral blackberry plants is a rapid, relatively risk-free method of producing uniformly vigorous and productive true-to-name plants (Swartz et al., 1983).

\section{Tissue culture-induced variation}

Callus is so often associated with somaclonal variation that some callus-derived variants have been called "calliclones" to denote their callus origin (Skirvin and Janick, 1976a). [The first tissue culturederived cultivar of any species was a calliclone of Pelargonium known as 'Velvet Rose' (Skirvin and Janick, 1976b)]. One reviewer even ventured that variation is "... only associated with regeneration through a callus or cell suspension phase and not with true micropropagation or meristem-tip culture" (Karp, 1989). The relationship between callus and somaclonal variation is so strong that many commercial laboratories try to avoid callus development at any stage of propagation.

Callus initiation in vitro occurs most readily on cut or exposed surfaces in contact with medium. Callus initiation is probably analogous to wound responses observed in vivo, which activates transposable elements and stimulates the appearance of stress-induced enzymes and specific by-products (McClintock, 1984).

However, variation is not limited to callus regenerants. Evans (1988) reports considerable variation for morphological traits (flower shape, leaf shape, plant height), pollen viability, and chromosome number among adventitious Nicotiana alata Link \& Otto plants regenerated directly from leaf explants without a callus intermediate. Variation also occurs among plants regenerated via embryogenesis.

Growth regulators. Growth regulators such as 2,4dichlorophenoxyacetic acid (2,4-D) and 6-benzylaminopurine (BA) have been implicated in the induction of variability (Evans, 1988; Griesbach et al., 1988; Shoemaker et al., 1991), but their direct relationship to this phenomenon is still debated.

Although the effect of specific growth regulators on variation remains unclear, most tissue culturists agree that variation rates are increased as the overall concentrations of growth regulators rise. High growth regulator concentrations also can alter the frequency of ploidy changes vs. point mutations. The excising process itself is probably enough to stimulate wound responses that growth regulators enhance (McClintock, 1984).

Cultivar. The amount of variation encountered in vitro is not the same for all cultivars of a species (Kurtz and Lineberger, 1983). Some cultivars show excessive variation, others are relatively stable. For instance, Hwang and Ko (1986) reported an overall variation rate of $3 \%$ among banana cultures, but the rate of variation for 'Cavendish' bananas was up to $20 \%$.

Cultivar age. Although older asexually propagated clones would be expected to show more preexisting variation than newer clones, there seems to be little correlation between clonal age and the amount of variation observed in a clone. Shepard et al. (1980) were among the first to report somaclonal variation. They found thousands of variants 
among their "protoclones" (protoplast-derived clones) of 'Russet Burbank' potato. Since the cultivar was old, a portion of its variation could have been logically assigned to preexisting natural mutations, chimeras (discussed earlier), or tissue culture conditions. However, it is more difficult to explain the large amount of variability observed in 'Maris Bard' potato (Thomas et al., 1982), which had been released as a cultivar only a few years earlier, in 1974. In the 'Maris Bard' study, all but one regenerant had unusual chromosome numbers ranging from 49 to 95 vs. 48 for the normal type.

Ploidy level. Since the ability to regenerate in vitro is a heritable trait in tomato (Lycopersicon esculentum Mill.) (Evans and Sharp, 1983; Kurtz and Lineberger, 1983), differences in cultivar response also could have a genetic basis. Variability seems to be highest among polyploid and high-chromosome species. One of the first important reports of somaclonal variation involved the isolation of callus lines from sugarcane, a plant with high chromosome numbers (Heinz and Mee, 1969). Heinz and Mee obtained callus lines that varied in their growth habits and color. Each of these lines was later found to have a different number of chromosomes. Similar differences were noted among regenerated plants (Heinz and Mee, 1971).

Bingham and McCoy (1986) generalized about the types of variation that one can expect in alfalfa as a function of the explant type and its original ploidy level: "When diploid alfalfa (Medicago sativa $\mathrm{L}$.) is regenerated, the most common type of chromosome variation is spontaneous doubling. When tetraploids are regenerated from callus cells or protoplasts, both aneuploidy and chromosome doubling are common, and some chromosome structural changes occur." Some of the variation identified at both ploidy levels has proved to be heritable.

Explant source. When exploring a new species or cultivar for somaclonal variation, it is a good idea to use several different explants and compare progeny from each. Not all explants should be assumed to exhibit variation equally. In general, variation is less likely to be observed from preformed shoots (axillary buds, shoot tips, and meristems) than from explants that have no preformed shoot meristems, such as leaves, roots, or protoplasts (discussed earlier). For instance, protoplasts of 'Russet Burbank' potato (Shepard et al., 1980) yielded thousands of variable progeny from which two or three advanced lines have been selected (Gary Secor, Dept. of Plant Pathology, North Dakota State Univ., Fargo, personal communication) for possible introduction. R.M.S. recently visited S. Ke(Wuhan Institute of Botany, People's Republic of China), who showed him protoclones of kiwifruit [Actinidia deliciosa (A. Chev.) C.F. Liang et A.R. Ferguson var. deliciosa] endosperm that varied in sex expression, growth habit, vigor, and leaf morphology. These results were published recently (Gui et al., 1993; Tsai et al., 1992).

Length of time in vitro. The length of time that a culture has been maintained in vitro is among the most important factors involved in inducing somaclonal variation. To maintain clonal stability, most commercial laboratories regularly sample their plants ex vitro in a field or greenhouse to make sure that the characteristics of the particular cultivar are maintained. In addition, most laboratories limit the number of subcultures that can be made from an explant. For instance, after 1 year all cultures established from a particular explant will be harvested. The clone will then be replaced with another explant taken from the original mother plant. To ensure continuity in a commercial enterprise, new cultures are established regularly and older ones eliminated on schedule.

When maintenance of clonal stability is mandatory (such as in a government germplasm repository), cultures can be stored in sealed containers under refrigeration or in liquid nitrogen (Reed, 1990; Reed and Lagerstedt, 1987). A 100-year project has been established in Oregon (Sherman, 1987) to study the effects of long-term storage of strawberry (Fragaria $\times$ ananassa Duch.) meristems.

In general, for clonal stability, minimize the amount of time that a culture is maintained in vitro. In contrast, long-term cultures can be an excellent source of variants.

Proliferation rate. Cultures proliferated at excessive rates show more variation than those grown at moderate rates. For instance, Smith and Drew (1990) report that pineapple [Ananas comosus (L.) Merrill] can be propagated by conventional cuttings and separation systems at four to five plants per year. In vitro, the rate can be 30 to 50 plants per month. However, the amount of variation at this rate was "unacceptable." When the proliferation rate was reduced to four per month, the rate of variation was "acceptable" at $5 \%$.

Selection pressure. Selection pressure in vitro has been used to select cell lines with resistance to disease, herbicides, particular chemical compounds, etc. Bingham and McCoy (1986) reported the selection of alfalfa cell lines with resistance or tolerance to ethionine, salt, and a fungal culture filtrate. However, among plants regenerated from these cultures, only the disease-resistant character was expressed at the whole-plant level. Widholm (1988) has reviewed the use of tissue culture to select cell lines of value to researchers and industry. He states that direct selection for single gene traits is more likely to be successful than for those with multigenic control.

For selection pressure schemes to be of long-term value for plant improvement, the trait selected at the cellular level must be expressed at the whole-plant level. However, it is not safe to assume that all genes that are expressed at the cellular level will be expressed in the same manner at the whole-plant level. For instance, Tabata (Scowcroft and Larkin, 1988) reported a cell line of tobacco that produced exceptional quantities of nicotine, but regenerated plants produced only normal levels. However, high nicotine production levels were reestablished in callus cultures of the regenerated plants. This difference indicated that the high-nicotine gene was present, but that it was only expressed at the cellular level. In contrast, for pharmaceutical products produced by cells, it may be less expensive to harvest the product directly from the cells and avoid the greater expense of maintaining whole plants.

Hammerschlag (1990) and Hammerschlag et al. (1991) have isolated peach [Prunus persica (L.) Batsch.] clones with putative resistance to Xanthomonas campestris pv. pruni. Some of these clones have continued to exhibit disease resistance for 2 years, while in others, the trait has proved transient. Seeds are now being collected from these plants to study the heritability of the trait among somaclones (Hammerschlag et al., 1991).

Researchers should remember that they are constantly subjecting their tissue cultures to selection pressure of some type. Widholm (1988), for instance, has suggested that tissue culture conditions are so unnatural for plant cells that only the most rapidly growing cells survive due to repeated subculturing. As evidence, he offers the universal observation that newly established suspension cultures are clumpy and grow slowly. In time, suspension culture growth rates accelerate and the size of aggregates decreases. Furthermore, he suggested that cell and tissue cultures do not grow equally well in all laboratories because they are unintentionally selected under the specific media and environmental conditions of a particular laboratory.

Cultural conditions. Genomic irregularities in plant and animal cell cultures occur most often when cells are removed from the stabilizing and controlling influences exerted by an intact organism and placed into an unnatural environment within a culture vessel. When a plant is excised and wounded in preparation for transfer to tissue culture, the control systems that regulate a whole plant are interrupted. For instance, in a whole plant, callus is a wound response that rarely results in sufficient organization to produce shoots or roots. However, in tissue culture, callus is a common phase through which excised plant parts commonly pass before organizing into a meristem that can yield roots, shoots, or both. Growth regulators and other in vitro stimuli mediate these events. It is not surprising, therefore, that adventitious shoot formation results in abnormal phenotypes.

\section{RATES OF SOMACLONAL VARIATION}

In the earliest tissue cultures, off-types were noted but generally rogued as undesirable. Later, visual analyses of regenerants were inadequate to appreciate the extent of variation. With biochemical and chromosomal analyses, the magnitude of change sometimes was as high as $100 \%$ (Orton, 1983), but rates of $15 \%$ to $20 \%$ were common (Evans and Sharp, 1983). These findings are in contrast to naturally occurring mutation rates of 1 in 100,000 to $1,000,000$ for a given locus. Larkin et al. (1984) reported 3\% to $26 \%$ variation for fertility in wheat (Triticum aestivum L.); Evans (1988) reported the frequency of singlegene mutations was about one mutant in every 20 to 25 regenerated plants. Orton (1987) reported that $100 \%$ of celery (Apium graveolens 
L.) lines isolated in vitro varied from the parental chromosomal condition. Although rates of somaclonal variation seem high, one should remember that somaclonal variation is a random phenomenon that can occur at any location in the genome. These random changes are pooled to arrive at the total somaclonal variation rates presented in most literature. The true rate of somaclonal variation is difficult to ascertain because there are so many individual genes to examine.

Many somaclones are identical, suggesting a common origin. Davies et al. (1986) showed that certain types of variation occurred repeatedly within groups of Paspalum dilatatum Poir. plantlets derived from the same explant source. They postulated that the abnormalities occurred at high rates because variation arose early in callus cultures and was proliferated and unintentionally selected as callus "sectors" through subsequent subcultures. Lee and Phillips (1987) made a similar observation with Zea mays L. They found that the same culture often yielded several plants that segregated for phenotypically identical variants. Such variation probably occurred early in culture initiation, leading to an overestimation of the frequency of somaclonal variation.

Based on literature and our professional experience, a more realistic level of somaclonal variation expected in vitro is probably about $1 \%$ to $3 \%$. This does not mean that a researcher should expect $1 \%$ to $3 \%$ of their regenerants to mutate at a particular locus, but it does mean that $1 \%$ to $3 \%$ of the regenerants will vary from their parent in some physical or biochemical manner. Although this rate of variation sounds less useful than the $25 \%$ to $100 \%$ levels discussed earlier, the researcher should remember that all of this variation occurs within a clone. Selection pressure can result in isolating unique forms of the parental clone. Conventional breeding procedures involving backcrossing can also yield improved forms of a clone, but the process can be time consuming, unsuccessful, and only work for plants that are self-compatible. Many important food crops, such as apple and pear (Pyrus spp. L.), are either self-incompatible or exhibit severe inbreeding depression.

Although variation rates of $1 \%$ to $3 \%$ may be realistic, even those rates are difficult to explain at the molecular level. For instance, there is a set of genes in wheat for the gliadins, which are involved in storage protein quality. Larkin et al. (1984) used the gliadins to quantify large amounts of variation and demonstrate the extent of variation available through in vitro procedures. However, Novoselskaya et al. (1987) traced variation in 50 gliadin-coding genes that could be distinguished by electrophoretic bands on gels. They found little variation, as did Maddock et al. (1985). Novoselskaya et al. (1987) and Metakovsky et al. (1987) suggested that the rate of variation observed among the gliadins was too high to be sensible. For instance, if we assume that, in terms of the genome, the gliadins are no different than any other site on chromosomes, then a change in one or two of the 50 gliadin genes represents a $2 \%$ to $4 \%$ rate of mutation throughout the genome. When this level is extrapolated to the whole genome, the rate of variation is so high that no viable offspring should be expected. However, it is also possible that the gliadin genes are inherently unstable under particular conditions, biasing conclusions from these studies.

In summary, somaclonal variation can be used for plant improvement. To date, somaclonal variation has been a random process that will become more useful as researchers learn to control and direct it to achieve specific goals. The development of regeneration protocols for recalcitrant species will facilitate access to natural and induced variations.

\section{Literature Cited}

Abo El-Nil, M.M. and A.C. Hildebrandt. 1971. Differentiation of virussymptomless geranium plants from anther callus. Plant Dis. Rptr. 55:10171020 .

Anonymous. 1989. Growers spot variations in tissue cultured stock. American Nurseryman 169(6):15-17.

Bingham, E.T. and J.T. McCoy. 1986. Somaclonal variation in alfalfa. Plant Breeding Rev. 4:123-152.

Brand, A.J. and M.P. Bridgen. 1989. 'UConn White': A white flowered Torenia fournieri. HortScience 24:714-715.

Bright, S., V. Jarrett, R. Nelson, G. Creissen, A. Karp, J. Franklin, P. Norbury, J. Kueh, S. Rognes, and B. Miflin. 1983. Modification of agronomic traits using in vitro technology, p. 251-265. In: S.H. Mantell and H. Smith (eds.). Plant biotechnology. Cambridge University Press, New York.

Broertjes, C. 1969. Mutation of breeding of Streptocarpus. Euphytica 18:333339.

Broertjes, C. and A. Keen. 1980. Adventitious shoots: Do they develop from one cell? Euphytica 29:73-87.

D'Amato, F. 1991. Nuclear changes in cultured plant cells. Caryologia 44:217224.

Darrow, G.M. 1931. A productive thornless sport of the Evergreen blackberry. J. Hered. 22:405-406.

Davies, L.J., D. Cohen, and K.V. Mullins. 1986. Somaclonal variation in the apomictic pasturegrass Paspalum dilatatum. N.Z. Agron. Soc. Spec. Publ. 5:355-360.

Dermen, H. 1960. Nature of plant sports. Amer. Hort. Mag. 39:123-173.

Evans, D.A. 1988. Applications of somaclonal variation, p. 203-223. In: A. Mizrahi (ed.). Biotechnology in agriculture. Allan R. Liss, New York.

Evans, D.A. and W.R. Sharp. 1983. Single gene mutations in tomato plants regenerated from tissue culture. Science 221:949-951.

Evans, D.A. and W.R. Sharp. 1986. Applications of somaclonal variation. Bio/ Technology 4:528-532.

Evans, D.A., W.R. Sharp, and H.P. Medina-Filho. 1984. Somaclonal and gametoclonal variation. Amer. J. Bot. 71:759-774.

Gengenbach, B.G. and P. Umbeck. 1982. Characteristics of T-cytoplasm revertants from tissue culture. Maize Genet. Coop. Nwsl. 56:140-142.

Griesbach, R.J. 1989. Selection of a dwarf Hemerocallis through tissue culture. HortScience 24:1027-1028.

Griesbach, R.J. and P. Semeniuk. 1987. Use of somaclonal variation in the improvement of Eustoma grandiflorum. J. Hered. 78:114-116.

Griesbach, R.J., P. Semeniuk, M. Roh, and R.H. Lawson. 1988. Tissue culture in the improvement of Eustoma. HortScience 23:791.

Gui, Y., S. Hong, S. Ke, and R.M. Skirvin. 1993. Fruit and vegetative characteristics of endosperm-derived kiwifruit (Actinidia chinensis $\mathrm{F}$ ) plants. Euphytica 71:57-62.

Hall, H.K., D. Cohen, and R.M. Skirvin. 1986a. Inheritance of thornlessness from tissue culture-derived 'Thornless Evergreen' blackberry. Euphytica 35:891-898.

Hall, H.K., H. Quazi, and R.M. Skirvin. 1986b. Isolation of a pure thornless 'Loganberry' by meristem tip culture. Euphytica 35:1039-1044.

Hall, H.K., R.M. Skirvin, and W.F. Braam. 1986c. Germplasm release of 'Lincoln Logan', a tissue culture-derived genetic thornless 'Loganberry'. Fruit Var. J. 40:134-135.

Hammerschlag, F.A. 1990. Somaclonal variation in peach, p. 170-183. In: Y.P.S. Bajaj (ed.). Biotechnology in agriculture and forestry. vol. 1. Trees I. Springer-Verlag, Berlin.

Hammerschlag, F.A., D. Ritchie, and D. Weaver. 1991. Phenotypic stability of bacterial leaf spot resistance in peach regenerants under greenhouse and field conditions. HortScience 26:725. (Abstr.)

Harris, M. 1964. Cell culture and somatic variation. Holt, Rinehart and Winston, New York.

Hartmann, H.T. and D.E. Kester. 1983. Plant propagation. Prentice-Hall, Englewood Cliffs, N.J.

Heath-Pagliuso, S., J. Pullman, and L. Rappaport. 1989. 'UC-T3 Somaclone': Celery germplasm resistant to Fusarium oxysporum f. sp. apii, race 2. HortScience 24:711-712.

Heinz, D.J. and G.W.P. Mee. 1969. Plant differentiation from callus tissue of Saccharum species. Crop Sci. 9:346-348.

Heinz, D.J. and G.W.P. Mee. 1971. Morphologic, cytogenetic, and enzymatic variation in Saccharum species hybrid clones derived from callus culture. Amer. J. Bot. 58:257-262.

Hwang, S.C. and W.H. Ko. 1986. Somaclonal variation of bananas and screening for resistance to Fusarium wilt, p. 151-156. In: G.J. Persley and E.A. DeLanghe (eds.). Banana and plantain breeding strategies. Austral. Centre Intl. Agr. Res. Proc. Ser. 21, Canberra.

Jackson, J.A. and R.F. Lyndon. 1990. Habituation: Cultural curiosity or developmental determinant? Physiol. Planta 79:579-583.

Karp, A. 1989. Can genetic instability be controlled in plant tissue cultures? Nwsl. Intl. Assn. Plant Tissue Culture 58:2-11.

Knuttel, A.J. 1989. Tissue culture troubles. Amer. Nurseryman 170(11):43-49.

Kurtz, S.M. and R.D. Lineberger. 1983. Genotypic differences in morphogenic capacity of cultured leaf explants of tomato. J. Amer. Soc. Hort. Sci. 108:710-714.

Larkin, P.J., S.A. Ryan, R.I.S. Brettell, and W.R. Scowcroft. 1984. Heritable somaclonal variation in wheat. Theor. Applied Genet. 67:443-455.

Larkin, P.J. and W.R. Scowcroft. 1981. Somaclonal variation-A novel source of variability from cell cultures for plant improvement. Theor. Applied Genet. 60:197-214.

Lee, M. and R.L. Phillips. 1987. Genetic variants in progeny of regenerated maize plants. Genome 29:834-838.

Maddock, S.E., R. Risiot, S. Parmar, M.G.K. Jones, and P.R. Shewry. 1985. 
Somaclonal variation in the gliadin patterns of grains of regenerated wheat plants. J. Expt. Bot. 36:1976-1984.

Marcotrigiano. M. 1990. Genetic mosaics and chimeras: Implications in biotechnology, p. 85-111. In: Y.P.S. Bajaj (ed.). Biotechnology in agriculture and forestry. vol. II. Springer-Verlag, Berlin.

Marcotrigiano, M. and K. Jagannathan. 1988. Paulownia tomentosa 'Somaclonal Snowstorm'. HortScience 23:226-227.

Maretzki, A. 1987. Tissue culture: Its prospects and problems, p. 343-384. In: D.J. Heinz (ed.). Sugarcane improvement through breeding. Elsevier, Amsterdam.

McClintock, B. 1984. The significance of responses of the genome to challenge. Science 226:792-801.

McPheeters, K. and R.M. Skirvin. 1983. Histogenic layer manipulation in chimera 'Thornless Evergreen' trailing blackberry. Euphytica 32:351-360.

McPheeters, K. and R.M. Skirvin. 1989. Somaclonal variation among ex vitro 'Thornless Evergreen' trailing blackberries. Euphytica 42:155-162.

Meins, F. 1982. Habituation of cultured plant cells, p. 3-31. In: G. Kahl and J.S. Schrell (eds.). Molecular biology of plant tumors. Academic, London.

Metakovsky, E.V., A. Yu Novoselskaya, and A.A. Sozinov. 1987. Problems of interpreting results obtained in studies of somaclonal variation in gliadin proteins in wheat. Theor. Applied Genet. 73:764-766.

Moore, J.N. and R.M. Skirvin. 1990. Blackberry management, p. 214-244. In: G.J. Galletta and D.G. Himelrick (eds.). Small fruit crop management. Prentice Hall, Englewood, Cliffs, N.J.

Moore, P.P., J.A. Robbins, and T.M. Sjulin. 1991. Field performance of 'Olympus' strawberry subclones. HortScience 26:192-194.

Moyer, J.W. and W.W. Collins. 1983. 'Scarlet' sweet potato. HortScience 18:111-112.

Novoselskaya, A. Yu, V.P. Upelniek, J. Sutka, G. Galiba, E.V. Metakovsky, and A.A. Sozinov. 1987. Studying somaclonal variation in wheat with the help of biochemical markers, p. 57-70. In: R. Lasztity and F. Bekes (eds.). Proc. 3rd Intl. Wkshp. Gluten Proteins. World Scientific, Teaneck, N.J.

Orton, T.J. 1983. Experimental approaches to the study of somaclonal variation. Plant Mol. Biol. Rpt. 1:67-76.

Orton, T.J. 1984. Somaclonal variation: Theoretical and practical considerations, p. 427-468. In: J.P. Gustafson (ed.). Gene manipulation in plant improvement. Plenum Press, New York.

Orton, T.J. 1987. Genetic instability in celery tissue and cell cultures. Iowa State J. Res. 61:481-498.

Ostry, M.E. and D.D. Skilling. 1987. Somaclonal variation in hybrid poplars for resistance to septoria leaf spot, p. 89-100. In: G.A. Tuskan (ed.). Proc. Fifth North Central Tree Improvement Conf., Fargo, N.D.

Reed, B.M. 1990. Survival of in vitro-grown apical meristems of Pyrus following cryopreservation. HortScience 25:111-113.

Reed, B.M. and H.B. Lagerstedt. 1987. Freeze preservation of apical meristems of Rubus in liquid nitrogen. HortScience 22:302-303.

Rosati, P., D. Gagglioli, and L. Giunchi. 1986. Genetic stability of micropropagated Loganberry plants. J. Hort. Sci. 61:33-41.

Scowcroft, W.R. 1985. Somaclonal variation: The myth of clonal uniformity, p. 217-245. In: B. Hohn and E.S. Dennis (eds.). Genetic flux in plants. Springer-Verlag, Wien.

Scowcroft, W.R. and P.J. Larkin. 1988. Somaclonal variation, p. 21-35. In: G. Bock and J. Marsh (eds.). Applications of plant cell and tissue culture. Ciba Foundation Symp. 137. Wiley, Chichester, U.K

Shepard, J.F., D. Bidney, and E. Shahin. 1980. Potato protoplasts in crop improvement. Science 208:17-24.

Sherman, H. 1987. Strawberry clones frozen in time. Arg. Res. 35:4.

Shoemaker, R.C., K.A. Amberger, R.G. Palmer, L. Oglesby, and J.P. Ranch. 1991. Effects of 2,4-dichlorophenoxyacetic acid concentration on somatic embryogenesis and heritable variation in soybean (Glycine max L. Mer. R.). In Vitro Cell Dev. Biol. 27:84-88.

Sibi, M. 1976. La notion de programme genétique chez les vegetaux superieurs II. Aspect experimental: Obtention de variants par culture de tissus in vitro sur Lactuca sativa L. Apparition de vigueur chez les croisements. Ann. l'Amelior. Plantes 26:523-547.

Skirvin, R.M. 1977. Fruit improvement through single cell culture. Fruit Var. J. 31:82-85.

Skirvin, R.M. 1978. Natural and induced variation in tissue culture. Euphytica 27:241-266

Skirvin, R.M. and J. Janick. 1976a. Tissue culture-induced variation in scented Pelargonium spp. J. Amer. Soc. Hort. Sci. 101:281-290.

Skirvin, R.M. and J. Janick. 1976b. 'Velvet Rose' Pelargonium, a scented geranium. HortScience 11:61-62.

Smith, M.K. and R.A. Drew. 1990. Current applications of tissue culture in plant propagation and improvement. Austral. J. Plant Physiol. 17:267-289.

Smith, M.K. and S.D. Hamill. 1991. Selecting dwarf off-types from tissue cultured bananas. Intl. Assn. Plant Tissue Culture IV Australian Branch Mtg. p. 13.

Stewart, R. and H. Dermen. 1970. Determination of number and mitotic activity of shoot apical initial cells by analysis of mericlinal chimeras. Amer. J. Bot. 57:816-826.

Swartz, H.J., G.J. Galletta, and R.H. Zimmerman. 1981. Field performance and phenotypic stability of tissue culture-propagated strawberries. J. Amer. Soc. Hort. Sci. 106:667-673.

Swartz, H.J., G.J. Galletta, and R.H. Zimmerman. 1983. Field performance and phenotypic stability of tissue culture-propagated thornless blackberries. J. Amer. Soc. Hort. Sci. 108:285-290.

Thomas, E., S.W.J. Bright, J. Franklin, R.W. Gibson, V. Lancaster, and B.J. Miflin. 1982. Variation amongst protoplast-derived potato plants (Solanum tuberosum cv. Maris Bard). Theor. Applied Genet. 62:65-68.

Tsai, C.K., Y.C. Chien, S.Q. Ke, Z.C.He, R.X. Jiang, Y.L.Zhou, Y.P. Ye, S.R. Hong, and R.H. Huang. 1992. Studies on the somaclonal variation of regenerated plants from protoplasts of Actinidia deliciosa. Acta Bot. Sinica 34(11):822-828.

Waldo, G.F. 1977. ‘Thornless Evergreen'-Oregon's leading blackberry. Fruit Var. J. 31:26-30.

Walduck, G., J. Daniells, and E. Gall. 1988. Results of a survey of off-types in tissue cultured Cavendish bananas in north Queensland. Bananatropics 8:11-12

Whitham, T.G., A.G. Williams, and A.M. Robinson. 1984. The variation principle: Individual plants as temporal and spatial mosaics of resistance to rapidly evolving pests, p. 15-51. In: P.W. Price, C.N. Slobodchikoff, and W.S. Gaud (eds.). A new ecology: Novel approaches to interactive systems. Wiley, New York.

Widholm, J.M. 1988. In vitro selection with plant cell and tissue cultures: An overview. Iowa State J. Res. 62:587-597. 


\title{
Development of New Cultivars via Anther Culture
}

\author{
Richard E. Veilleux \\ Department of Horticulture, Virginia Polytechnic Institute and State University, Blacksburg, VA 24061
}

Since the technique of anther culture was first reported (Guha and Maheshwari, 1966), its promise as a means of generating haploid plants that might be instrumental in developing new cultivars of major crop species has been impatiently awaited. By placing immature anthers containing microspores at the late uninucleate/early binucleate stage of development onto a synthetic medium, development can be modified such that some microspores proceed along an embryogenic, or androgenetic, pathway. By conversion of such embryos into plants, or regeneration of microspore-derived callus, haploid plants can be obtained. Subsequently, the chromosome number of such haploids can be doubled to yield homozygous inbred lines. At first, the technique was limited to only a few species; however, with refinements in tissue culture and selection of responsive genotypes, androgenesis has been observed in a wide array of crops representing diverse taxonomic groups (Bajaj, 1990). Given the length of time generally required to develop new cultivars, we can only now begin to expect release of cultivars that owe their origin to anther culture (Table 1). The citations in this table are not necessarily the first anther culture reports for each crop, but the first reports where haploid green plants were produced. Some species used in early anther culture work are not included in the list because of the difficulties that subsequent researchers encountered when applying the techniques to obtain haploid plants (e.g., tomato).

Using anther culture for plant improvement depends on the breeding system of a crop. For self-pollinated crops, such as wheat (Triticum aestivum L.), rice (Oryza sativa L.), or tomato (Lycopersicon esculentum Mill.), anther culture can be most effectively applied to an $\mathrm{F}_{1}$ hybrid between two breeding lines with complementary characteristics of agricultural significance to fix homozygosity in a single generation, thus avoiding the time required for several generations of inbreeding. Anther-derived doubled haploids could be released directly as cultivars once their field performance has been sufficiently documented. Two possibilities exist for applying anther culture to cross-pollinated crops, depending on whether homozygous lines and hybrid cultivars are already available. If they are available, e.g., maize (Zea mays L.), then anther culture can be used to develop additional inbred lines, as in self-pollinated crops. The difference is that the superior inbred lines developed by anther culture would not be grown directly as cultivars, but would be used to generate hybrid cultivars. For crops where completely homozygous inbred lines are either not already available or difficult to develop, e.g., Brassica or Asparagus, anther culture offers a new means to obtain them. Survival as a haploid provides an immediate and efficient selection against deleterious and lethal genes. Because only a single allele is present at each locus, expression of such deleterious recessive alleles is guaranteed with the result that embryos or plants bearing them will perish through the "monoploid sieve" (Wenzel et al., 1979). Also, derivation of haploids does not depend on male and female fertility, as does inbreeding. Of course, once doubled haploids have been obtained, fertility is generally a prerequisite to their use in further breeding. Finally, for highly heterozygous, clonally propagated crops such as potato (Solanum tuberosum L.), heterogeneity among seedlings derived from heterozygous parents is generally too great for most agronomic characters for releasing and producing hybrid cultivars on a massive scale. Anther culture provides the potential to develop homozygous inbreds for $F_{1}$ hybrid production without sacrificing uniformity, thereby converting propagation from vegetative to hybrid seed.

Work has progressed on all of the above applications of anther culture toward cultivar development. In some instances, a general reduction in vigor has been associated with anther-derived doubled haploids (Baenziger et al., 1989; Marburger and Jauhar, 1989), even

The cost of publishing this paper was defrayed in part by the payment of page charges. Under postal regulations, this paper therefore must be hereby marked advertisement solely to indicate this fact. in comparison with haploids obtained by other means (Powell et al., 1986). Although lowered vigor has not always been the case, it has led to some concern about undesirable gametoclonal variation generated as part of the process. An unexpected elevation of DNA content per cell has been observed among some anther-derived lines (De Paepe et al., 1982; Dhillon et al., 1983), although no general association could be made between agronomic performance and DNA content (Reed and Wernsman, 1989). However, reduction in vigor has not been general and superior anther-derived lines have been reported for several crops (Deaton et al., 1982; de Buyser et al., 1985; Friedt and FouroughiWehr, 1983; Kubba et al., 1989; Schaeffer et al., 1984; Winzeler et al., 1987). The amount of variation obtained, even when the anther donor has been an inbred line, is remarkable. New cultivars that owe their origin to anther culture have been released, mainly in China and France. It is still too soon to determine if these cultivars will have enduring agricultural impact, but some appear promising.

\section{Cultivar development in self-pollinated crops}

Wheat (Triticum aestivum L.). Several cultivars of wheat have been released in China as a direct result of anther culture (Han, 1986). The development of 'Jinghua No. 1' has been most completely described (Daofen, 1986). From the $F_{1}$ of a cross between $F_{1}$ (Lovrin $18 \times 5238-036) \times$ Hongliang No. 4, 400 anthers were cultured. Fortysix anther-derived green plants were obtained, from which 28 selffertile plants were produced after chromosome doubling by colchicine. Seed was increased for these 28 lines, and one line was selected for good performance in field evaluations. After 3 years of regional testing, just 6 years after the initial cross had been made to generate the anther donor, the selected line was released as 'Jinghua No. 1'. More recently, 'Anther Culture 28' has been released in China following a similar protocol, except by selection among the anther-derived plants in the greenhouse for resistance to Erysiphe graminis DC. ex Mérat ; 'Anther Culture 28' demonstrated immunity in the field to the same pathogen (Zhao et al., 1990).

A similar scheme was used by de Buyser et al. (1987) in France for the development of 'Florin', a doubled haploid wheat cultivar. The initial cross was between 'Wizard' and 'Iena', from which 49,266 anthers of the $\mathrm{F}_{1}$ plants were placed into culture. Only 64 green plants were obtained, of which 54 were haploids and 10 spontaneous diploids. Forty-one of the 54 haploids were successfully doubled by colchicine; both these and the 10 spontaneous diploids were increased in the field for two seasons. Eighteen selections were field-tested for 2 years at two locations. Two of these were selected for official tests for registration. Of these, 'Florin', a doubled haploid that resulted from the colchicine treatment, was named, just 7 years after the cross was made to generate the anther donors.

Table 1. Major crop species for which the techniques for derivation of androgenetic haploid plants have been available sufficiently long to begin to expect cultivar releases and the reference in which the derivation of haploid green plants was documented.

\begin{tabular}{ll}
\hline Crop species & \multicolumn{1}{c}{ Reference } \\
\hline Asparagus officinalis & Pelletier et al. (1972) \\
Brassica napus & Wenzel et al. (1977) \\
Brassica oleracea & Kameya and Hinata (1970) \\
Capsicum annuum & Wang et al. (1973) \\
Hordeum vulgare & Clapham (1973) \\
Nicotiana tabacum & Nitsch and Nitsch (1969) \\
Oryza sativa & Niizeki and Oono (1968) \\
Secale cereale & Thomas et al. (1975) \\
Solanum tuberosum & Dunwell and Sunderland (1973) \\
Triticum aestivum & Ouyang et al. (1973); \\
& Picard and de Buyser (1973) \\
Zea mays & 401 Research Group (1975) \\
\hline
\end{tabular}


Rice (Oryza sativa $L$.). Several rice cultivars have been released in China (Table 2) following procedures similar to cultivar development in wheat, i.e., anther culture following hybridization to derive truebreeding, self-pollinated cultivars. The development of 'Hua Han Zhao' (in Chen, 1986) deserves particular attention because two cycles of anther culture were used to combine characteristics from several parents (Fig. 1). Anther culture also has been used to develop inbred rice lines that equal or exceed the vigor and yield of the hybrid cultivars from which they were derived (Zhu and Pan, 1990). Anther-derived rice cultivars are now grown extensively in China.

Tobacco (Nicotiana tabacum L.). Tobacco, a self-pollinating allotetraploid, is the crop for which anther culture techniques can be most efficiently applied. Plantlets emerge directly from anthers in culture, thus eliminating the embryo conversion step. Additionally, the haploid plant frequency is high, haploid plants have a high survival rate on transfer to the greenhouse, and the procedure for chromosome doubling of haploids is simple and efficient. These features have generated a wealth of scientific literature on the performance and features of anther-derived haploids; yet, cultivar release has been disappointing. Three anther-derived tobacco cultivars, 'Tan Yuh 1', 'Tan Yuh 2', and 'Tan Yuh 3', have been released in China (Research Laboratory of Breeding, 1981). However, the North Carolina breeding program recently eliminated their most advanced anther-derived breeding line, NC 744, when it failed a smoke panel evaluation; NC 744 was released as germplasm rather than as a cultivar (Chaplin et al., 1980). The Kentucky and North Carolina breeding programs have released several additional anther-derived germplasm lines of tobacco as sources of pathogen resistance (Nielsen, 1989; Rufty et al., 1990). It remains to be seen if an important North American tobacco cultivar will be released through the application of anther culture.

\section{Cross-pollinated crops}

Maize (Zea mays $L$.). Maize has been the classic example of the power of plant breeding through development of inbred lines followed by subsequent cross pollination between selected inbreds to generate highly heterotic hybrid cultivars. The development of inbred lines has progressed during this century such that double-cross hybridsoriginally required because of the lack of vigor and poor seed set of early inbred lines - are no longer necessary; single crosses between more vigorous inbreds provide most of the maize seed currently used for production (Simmonds, 1979). Using anther culture for rapid development of superior inbreds has been attractive to seed companies

Table 2. Cultivars or germplasm of major crop plants developed by application of anther culture.

\begin{tabular}{lllcl}
\hline \hline \multirow{2}{*}{ Crop } & \multicolumn{1}{c}{ Cultivar } & Country & released & \multicolumn{1}{c}{ Reported by } \\
\hline Asparagus & Andreas & France & 1990 & Corriols et al. (1990) \\
Maize & Huayu 1 & China & 1986 & Wu (1986) \\
Rice & Hua Yu I and II & China & 1976 & Hu and Zeng (1984) \\
& Xin Xiu & China & 1976 & Loo and Xu (1986) \\
& Late Keng 959 & China & 1978 & Loo and Xu (1986) \\
& Tung Hua 1, 2, 3 & China & 1978 & Loo and Xu (1986) \\
& Zhonghua 8 and 9 & China & 1981 & Chen (1986) \\
& Hua Han Zao & China & 1982 & Chen (1986) \\
& Huajian 7902 & China & 1983 & Chen (1986) \\
& Nanhua 5 & China & 1983 & Loo and Xu (1986) \\
& Noll & China & 1983 & Loo and Xu (1986) \\
& Hua 03 & China & 1989 & Yang and Fu (1989) \\
& Guan 18 & China & 1990 & Zhu and Pan (1990) \\
Tobacco & Tan Yuh 1, 2, 3 & China & 1974 & Hu and Zeng (1984) \\
& NC 744y & USA & 1980 & Chaplin et al. (1980) \\
& KDH 926, 959, 960 & USA & 1989 & Nielsen (1989) \\
& NCBMR 42 and 90y & USA & 1990 & Rufty et al. (1990) \\
Wheat & Jinghua 1 & China & 1986 & Daofen (1986) \\
& Florin & France & 1987 & de Buyseret al.(1987) \\
& Anther culture 28 & China & 1990 & Zhao et al. (1990) \\
\hline
\end{tabular}

${ }^{2}$ Many of the original reports are in Chinese and not readily available in most libraries. In these cases, a summary article in English has been cited rather than the original report of release.

${ }^{\mathrm{y}}$ Germplasm lines released rather than cultivars.

\section{'Jianong 485' $\times$ 'Labelit'}

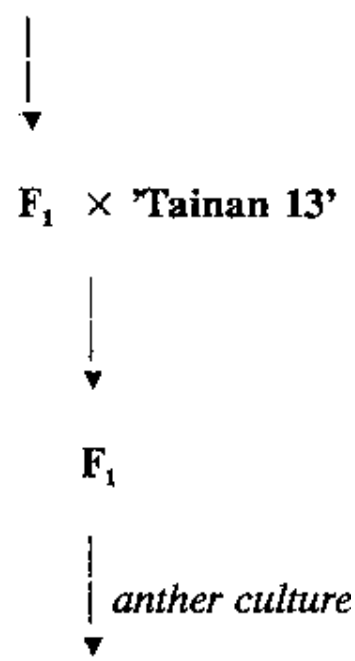

\section{'KeC 1669' $\times$ pollen line 175}

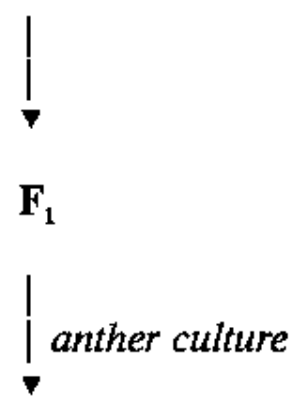

pollen line 76057

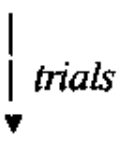

\section{'Hua Han Zhao'}

Fig. 1. Two cycles of anther culture for developing multiparental 'Hua Han Zhao' rice (after Chen, 1986).

for years; however, maize has been more recalcitrant to anther culture than other Gramineae. Chinese researchers have developed a viable anther culture protocol for maize and have been the first to release a cultivar, 'Huayu 1', for which one parent is an anther-derived inbred (Wu, 1986). Several U.S. seed companies are now using anther culture techniques for inbred line development (J.F. Petolino, personal communication).

Asparagus (Asparagus officinalis L.). Anther culture has a unique and recently exploited potential in asparagus breeding, i.e., the development of inbred lines that can be used to generate hybrid, all-male cultivars. Due to dioecy, selfing is generally impossible, except in the occasional andromonoecious cultivars. Sex expression in asparagus may be due to a single gene or gene complex on one chromosome with female and male plants being homomorphic and heteromorphic, respectively, with maleness dominant (Ellison, 1986). Although parthenogenetic haploids have been available in breeding programs for years, they have generally been female plants; anther culture has allowed the development of homozygous supermale plants that can generate all-male progeny when crossed to a female (Doré, 1990). Various parthenogenetic and anther-derived lines have been devel- 
polyenbryonic seed

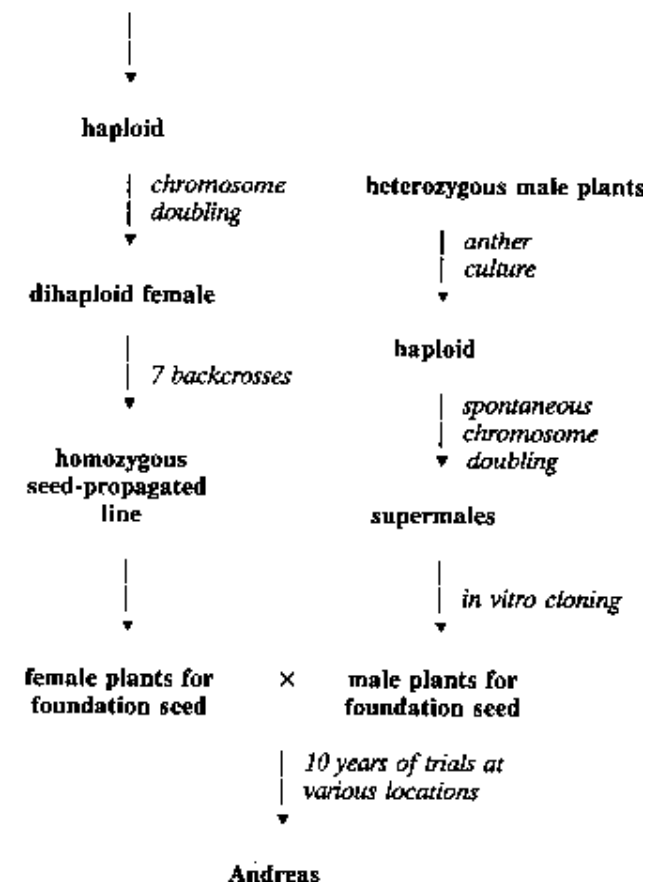

Fig. 2. Breeding scheme for development of 'Andreas', an all-male homogeneous $\mathrm{F}_{1}$ hybrid Asparagus (Corriols et al., 1990).

oped in France, and their hybrids have been evaluated in a breeding program for several years. The first anther-derived, all-male hybrid cultivar, 'Andreas', was recently released (Corriols et al., 1990). The homozygous female parent of 'Andreas' is a parthenogenetic doubled haploid, whereas the homozygous supermale parent is an antherderived doubled haploid (Fig. 2). Yield trials conducted at several locations in different years showed a yield advantage for 'Andreas' compared to leading cultivars (Corriols et al., 1990).

\section{CONCLUSION}

Anther culture is a powerful technique that, within 20 years of its discovery, has begun to have an impact on cultivar release. The short time required to develop completely homozygous lines is the major advantage of anther culture. Most of the anther-derived cultivars to date have been released in China, thus making it difficult to assess their impact. It is also difficult to know how the standards and evaluations for cultivar release in China compare with those in the West, although there are several accounts in which extensive cultivation of antherderived cultivars in China has been reported (Hu and Zeng, 1984; Loo and Yu, 1986; Picard et al., 1990; Zhao et al., 1990). In various breeding programs around the world, androgenetic doubled haploids are being used extensively for cultivar development in eggplant (Solanum melongena L.), pepper (Capsicum annuum L.), barley (Hordeum vulgare L.), and rape (Brassica napus L.). Anther-derived inbred lines of potato that have female fertility have recently been reported (M'Ribu and Veilleux, 1990). A limitation of the technique is that it can be used only on competent germplasm, which depends on the species. As the procedures for anther culture become more routine, and if the technique of anther culture does not become generally associated with the phenomenon of undesirable gametoclonal variation leading to reduction in vigor, we may expect to see its more general application to cultivar development over a wide range of crops.

\section{Literature Cited}

Baenziger, P.S., D.M. Wesenberg, V.M. Smail, W.L. Alexander, and G.W. Schaeffer. 1989. Agronomic performance of wheat doubled-haploid lines derived from cultivars by anther culture. Plant Breeding 103:101-109.

Bajaj, Y.P.S. 1990. In vitro production of haploids and their use in cell genetics and plant breeding, p. 1-44. In: Y.P.S. Bajaj (ed.). Biotechnology in agriculture and forestry 12: Haploids in crop improvement I. SpringerVerlag, Berlin.

Chaplin, J.F., L.G. Burk, G.V. Gooding, and N.T. Powell. 1980. Registration of NC 744 tobacco germplasm. Crop Sci. 20:677.

Chen, Y. 1986. The inheritance of rice pollen plant and its application in crop improvement, p. 118-136. In: H. Hu and H. Yang (eds.). Haploids of higher plants in vitro. Springer-Verlag, Berlin.

Clapham, D. 1973. Haploid Hordeum plants from anthers in vitro. Z. Pflanzenzüchtg. 69:142-155.

Corriols, L., C. Doré, and C. Rameau. 1990. Commercial release in France of Andreas, the first asparagus all-male F1 hybrid! Proc. 7th Intl. Asparagus Symp., 19-23 June 1989, Ferrara, Italy. Acta Hort. 271:249-252.

Daofen, H. 1986. Jinghua No. 1, a winter wheat variety derived from pollen sporophyte, p. 137-148. In: H. Hu and H. Yang (eds.). Haploids of higher plants in vitro. Springer-Verlag, Berlin.

de Buyser, J., Y. Henry, and G. Taleb. 1985. Wheat androgenesis: Cytogenetical analysis and agronomic performance of doubled haploids. Z. Pflanzenzüchtg. 95:23-34.

de Buyser, J., Y. Henry, P. Lonnet, R. Hertzog, and A. Hespel. 1987. 'Florin': A doubled haploid wheat variety developed by the anther culture method. Plant Breeding 98:53-56.

De Paepe, R., D. Prat, and T. Huguet. 1982. Heritable nuclear DNA changes in doubled haploid plants obtained by pollen culture of Nicotiana sylvestris. Plant Sci. Lett. 28:11-28.

Deaton, W.R., P.D. Legg, and G.B. Collins. 1982. A comparison of burley tobacco doubled-haploid lines with their source inbred cultivars. Theor. Applied Genet. 62:69-74.

Dhillon, S.S., E.A. Wernsman, and J.P. Miksche. 1983. Evaluation of nuclear DNA content and heterochromatin changes in anther-derived dihaploids of tobacco (Nicotiana tabacum) cv. Coker 139. Can. J. Genet. Cytol. 25:169-173.

Doré, C. 1990. Asparagus anther culture and field trails of dihaploids and F1 hybrids, p. 322-345. In: Y.P.S. Bajaj (ed.). Biotechnology in agriculture and forestry 12: Haploids in crop improvement I. Springer-Verlag, Berlin.

Dunwell, J.M. and N. Sunderland. 1973. Anther culture of Solanum tuberosum L. Euphytica 22:317-323.

Ellison, J.H. 1986. Asparagus breeding, p. 521-569. In: M.J. Bassett (ed.). Breeding vegetable crops. AVI, Westport, Conn.

Friedt, W. and B. Foroughi-Wehr. 1983. Field performance of androgenetic doubled haploid spring barley from $F_{1}$ hybrids. Z. Pflanzenzüchtg. 90:177-184 .

Guha, S. and S.C. Maheshwari. 1966. Cell division and differentiation of embryos in the pollen grains of Datura in vitro. Nature 212:97-98.

Han, H. 1986. Wheat: Improvement through anther culture, p. 55-72. In: Y.P.S. Bajaj (ed.). Biotechnology in agriculture and forestry 2: Crops I. SpringerVerlag, Berlin.

Hu, H. and J.Z. Zeng. 1984. Development of new varieties via anther culture, p. 65-90. In: P.V. Ammirato, D.A. Evans, W.R. Sharp, and Y. Yamada (eds.). Handbook of plant cell culture. vol. 3. Crop species. Macmillan, New York.

Kameya, T. and K. Hinata. 1970. Induction of haploid plants from pollen grains of Brassica. Jpn. J. Breeding 20:82-87.

Kubba, J., B.M. Smith, D.J. Ockendon, A.P. Setter, C.P. Werner, and M.J. Kearsey. 1989. A comparison of anther culture derived material with single seed descent lines in Brussels sprouts (Brassica oleracea var. gemmifera). Heredity 63:89-95.

Loo, S.-W. and Z.H. Xu. 1986. Rice: Anther culture for rice improvement in China, p. 139-156. In: Y.P.S. Bajaj (ed.). Biotechnology in agriculture and forestry 2: Crops I. Springer-Verlag, Berlin.

Marburger, J.E. and P.P. Jauhar. 1989. Agronomic, isozyme, and cytogenetic characteristics of 'Chris' wheat doubled haploids. Plant Breeding 103:7380.

M'Ribu, H.K. and R.E. Veilleux. 1990. Field evaluation of the breeding value of doubled monoploids from a clone of the diploid potato species, Solanum phureja Juz. \& Buk. Amer. Potato J. 67:566. (Abstr.)

Nielsen, M.T. 1989. Registration of KDH 926, KDH 959, KDH 960 tobacco germplasm lines with different levels of trichome exudate constituents. Crop Sci. 29:1584

Niizeki, H. and K. Oono. 1968. Induction of haploid rice plant from anther culture. Proc. Jpn. Acad. 44:554-557.

Nitsch, J.P. and C. Nitsch. 1969. Haploid plants from pollen grains. Science 163:85-87.

Ouyang, T.W., H. Hu, C.C. Chuang, and C.C. Tseng. 1973. Induction of pollen plants from anthers of Triticum aestivum L. cultured in vitro. Sci. Sinica 16:79-95.

Pelletier, G., C. Raquin, and G. Simon. 1972. La culture in vitro d'anthères d'asperge (Asparagus officinalis). C.R. Acad. Sci. 247:848-851.

Picard, E. and J. de Buyser. 1973. Obtention de plantules haplö̈des de Triticum aestivum L. à partir de culture d' anthères in vitro.C.R. Acad. Sci. 277:14631466.

Picard, E., A. Rode, G. Doussinault, M. Rousset, and M. Rives. 1990. Wheat 
(Triticum aestivum): In vitro production and utilization of doubled haploids, p. 101-124. In: Y.P.S. Bajaj (ed.). Biotechnology in agriculture and forestry. vol. 12: Haploids in crop improvement I. Springer-Verlag, Berlin.

Powell, W., P.D.S. Caligari, and J.M. Dunwell. 1986. Field performance of lines derived from haploid and diploid tissues of Hordeum vulgare. Theor. Applied Genet. 72:458-465.

Reed, S.M. and E.A. Wernsman. 1989. DNA amplification among antherderived doubled haploid lines of tobacco and its relationship to agronomic performance. Crop Sci. 29:1072-1076.

401 Research Group, Laboratory of Plant Cell and Tissue Culture, Institute of Genetics, Academia Sinica. 1975. Primary study on induction of pollen plants of Zea mays. Acta Genet. Sin. 2:143.

Research Laboratory of Breeding. 1981. A preliminary study on the heredity and vitality of the progenies of tobacco pollen plants, p. 223-225. In: H. Hul (ed.). Plant tissue culture. Proc. Symp. Plant Tissue Culture, Peking, 1978. Pitman Publishing, London.

Rufty, R.C., E.A. Wernsman, C.E. Main, and G.V. Gooding, Jr. 1990. Registration of NC-BMR 42 and NC-BMR 90 germplasm lines of tobacco. Crop Sci. 30:241-242.

Schaeffer, G.W., F.T. Sharpe, Jr., and P.B. Cregan. 1984. Variation for improved protein and yield from rice anther culture. Theor. Applied Genet. 67:383-389.

Simmonds, N.W. 1979. Principles of crop improvement. Longman, London.

Thomas, E., F. Hoffman, and G. Wenzel. 1975. Haploid plantlets from microspores of rye. Z. Pflanzenzüchtg. 75:106-113.
Wang, Y., C. Sun, C. Wang, and N. Chien. 1973. The induction of the pollen plantlets of Triticale and Capsicum annuum from anther culture. Sci. Sinica 16:147-151.

Wenzel, G., F. Hoffmann, and E. Thomas. 1977. Anther culture as a breeding tool in rape. I. Ploidy level and phenotype of androgenetic plants. Z. Pflanzenzüchtg. 78:149-155.

Wenzel, G., O. Schieder, T. Przewozny, S.K. Sopory, and G. Melchers. 1979. Comparison of single cell culture derived Solanum tuberosum L. plants and a model for their application in breeding programs. Theor. Applied Genet. 55:49-55.

Winzeler, H., J. Schmid, and P.M. Fried. 1987. Field performance of androgenetic, doubled haploid spring wheat lines in comparison with lines selected by the pedigree system. Plant Breeding 99:41-48.

Wu, J. 1986. Breeding haploid corn by anther culture, p. 149-161. In: H. Hu and H. Yang (eds.). Haploids of higher plants in vitro. Springer-Verlag, Berlin.

Yang, X. and H. Fu. 1989. Hua-03 - A high protein indica rice. Intl. Rice Res. Nwsl. 14(3):14-15.

Zhu, D. and X. Pan. 1990. Rice (Oryza sativa L.): Guan 18-An improved variety through anther culture, p. 204-211. In: Y.P.S. Bajaj (ed.). Biotechnology in agriculture and forestry 2: Haploids in crop improvement I. Springer-Verlag, Berlin.

Zhao, Y., X. He, J. Wang, and W. Liu. 1990. Anther culture 28-A new diseaseresistant and high-yielding variety of winter wheat, p. 353-362. In: Y.P.S. Bajaj (ed.). Biotechnology in agriculture and forestry 13: Wheat. SpringerVerlag, Berlin.

\title{
Observations and Suggestions for Improving Somatic Hybridization by Plant Protoplast Isolation, Fusion, and Culture
}

\author{
Jude W. Grosser ${ }^{1}$ \\ Department of Horticultural Sciences, Citrus Research and Education Center, University of Florida, Institute of \\ Food and Agricultural Sciences, 700 Experiment Station Road, Lake Alfred, FL 33850
}

\begin{abstract}
Methods for the isolation and culture of Citrus protoplasts and subsequent plant regeneration are well developed (Grosser and Chandler, 1987; Grosser and Gmitter, 1990a; Kobayashi et al., 1983; Vardi and Galun, 1988; Vardi et al., 1982). Since the first report of somatic hybrid plant recovery in Citrus (Ohgawara et al., 1985), protoplast fusion techniques have been used to generate somatic hybrid plants from more than 30 parental combinations, including 25 from my laboratory (for reviews, see Gmitter et al., 1992; Grosser, 1991; Grosser and Gmitter 1990a, 1990b), and somatic cybrid plants from five combinations (Vardi et al., 1987, 1989). The comments and suggestions provided herein are based on my observations from research on Citrus, with lesser emphasis on Trifolium, but they may also be applicable to other plant protoplast systems, particularly woody species.
\end{abstract}

\section{Protoplast culture media development}

The complex 8P protoplast culture medium of Kao and Michayluk (1975) has been used for successful protoplast culture and plant regeneration of many plant species. The success of this complex medium is probably due to the appropriate concentrations of the multivitamin, organic acid, and sugar/alcohol additives that are combined with the basal medium formulation. These additives seem to provide additional buffering capacity and reduce the environmental stress on protoplasts by providing required metabolic intermediates.

Florida Agricultural Experiment Station Journal Series no. R-01899. The cost of publishing this paper was defrayed in part by the payment of page charges. Under postal regulations, this paper therefore must be hereby marked advertisement solely to indicate this fact.

${ }^{1}$ Associate Professor, plant cell genetics.
However, optimal basal tissue culture media have been developed for most plant genera, and an efficient protoplast culture medium may be developed for a particular genus by simply supplementing the optimal basal medium with $8 \mathrm{P}$ multivitamin, organic acid, and sugar/alcohol additives. This approach has been successful for Trifolium (Grosser and Collins, 1984; Myers et al., 1989) and Citrus (Grosser, 1991; Grosser and Gmitter, 1990a). Reducing or eliminating the ammonia content of the basal medium may also be useful. Most basal media contain high levels of $\mathrm{NH}_{4} \mathrm{NO}_{3}$ that can often be toxic to protoplasts. Glutamine or $\mathrm{Ca}\left(\mathrm{NO}_{3}\right)_{2}$ have been found to be good alternative sources of $\mathrm{N}$ in protoplast culture media, as demonstrated in BH3 Citrus protoplast medium (Grosser and Gmitter, 1990a) and Populus protoplast media (Russell and McCown, 1986).

Filter-sterilize all protoplast media, enzyme, and fusion solutions. Finally, use fresh protoplast culture media whenever possible, although protoplast culture media can be stored frozen or under refrigeration in brown bottles to prevent photo-oxidation.

\section{Protoplast isolation}

The importance of clean preparations of quality protoplasts cannot be overemphasized, and this starts with appropriate source material. Take leaves for protoplast isolation from vigorous and healthy plants grown under high-humidity and low-light conditions. I recommend using fully expanded, slightly hardened leaves from seedlings or from new flush of older plants. Growth chamber-grown leaves should be free of insecticide residue. When feathering leaves, use a sharp scalpel and avoid cutting near veins in larger, more developed leaves. Vacuum infiltration at 105 to $140 \mathrm{kPa}$ for 15 to $30 \mathrm{~min}$ is useful to increase enzyme penetration; leaves with compact parenchyma tissue may require more time in vacuum. Decontamination should not damage or 
dehydrate leaves (as indicated by burning or water soaking). Remove damaged sections of leaves before enzyme treatment. Grow genotypes with leaves that are over-sensitive to decontamination procedures in vitro to avoid this step.

Callus or suspension cultures used for protoplast isolation should be in the log phase of growth at the time of isolation. Friable tissue with low starch content generally gives the best results. Citrus embryogenic cultures can often require continual subculturing for long periods (often more than 1 year) before they reach adequate friability and appropriate starch levels for protoplast manipulation. Transferring Citrus callus to glutamine-containing media can sometimes reduce the starch content of cells to appropriate levels for protoplast isolation.

Use quality enzymes (e.g., cellulases, macerases, and pectolyases) whenever possible, as they liberate protoplasts more quickly and reduce exposure to harmful impurities. Desalting most pectinases, hemicellulases, and driselase before use may be beneficial. Combining an enzyme solution with a complex protoplast culture medium may reduce stress on protoplasts during isolation and thereby increase viability. Determine enzyme quality and quantity, time of exposure, and the concentration of osmoticum empirically. Overexposure to enzymes can weaken protoplast plasmalemmae and reduce viability. Excessive protoplast breakage can sometimes be reduced by increasing the concentration of the osmoticum. Gentle agitation by low-speed rotary shaking $(25-50 \mathrm{rpm})$ may facilitate protoplast liberation. Carry out isolations at a temperature that allows for high enzyme activity yet good protoplast viability (25-28C), and in darkness (most protoplasts are sensitive to light).

Purify protoplasts through a $45-\mu \mathrm{m}$ stainless steel or nylon filter to remove undigested cell clumps and large debris. Make reusable filters from the plastic reservoirs of Luer Lok 30-ml plastic syringes (Becton Dickinson \& Co., Rutherford, N.J.) and 45- $\mu \mathrm{m}$ stainless steel mesh (Gilson Co., Worthington, Ohio). Remove the upper $5 \mathrm{~cm}$ of the plastic reservoir with a hacksaw and melt it onto the stainless steel mesh using a hot plate. Trim excess mesh with sharp scissors. Resulting filters can withstand repeated autoclaving.

Particulate debris resulting primarily from broken protoplasts can reduce culture $\mathrm{pH}$, protoplast viability, and fusion frequency. Use a $25 \%$ sucrose : $13 \%$ mannitol or other gradient (Grosser and Gmitter, 1990a; Harms and Potrykus, 1978) to minimize this problem. I recommend this gradient for all protoplast preparations.

\section{Protoplast fusion}

The most successful methods used to generate somatic hybrid plants rely on the chemical polyethylene glycol (PEG) to induce protoplast adhesion and fusion. PEG is reliable, inexpensive, and nonphytotoxic to plant protoplasts if over-exposure is avoided. Historically, high-molecular-weight PEG (MW 6000-8000) has been used, but more recently, Chand et al. (1988) reported that $1500 \mathrm{MW}$ (Aldrich Chemical Co., Milwaukee) was more efficient. I recommend the procedure of Menczel et al. (1981), as modified by Grosser and Gmitter (1990a). Monitor the $\mathrm{pH}$ of prepared PEG solutions weekly, because they acidify rapidly. Because smaller protoplasts fuse at lower frequencies than larger ones, use equal volumes rather than equal densities of protoplasts from each parental source to maximize fusion frequency. Protoplast density also effects fusion frequency and culturability; higher densities can reduce fusion frequency. Adjust protoplast densities on a pellet: medium (v/v) basis following centrifugation of mixed protoplasts (Grosser and Gmitter, 1990a). The fusion of callus- or suspension-derived protoplasts with leaf-derived protoplasts facilitates fusion frequency determinations. Fusions of this combination also seem to result in enhanced somatic embryogenesis and subsequent plant recovery. Add PEG solution immediately after plating out mixed protoplasts, before parental types segregate according to buoyancy. Adjust the duration of exposure to PEG and elution solutions to achieve a balance between fusion frequency and postfusion protoplast viability. Genotypes that liberate fragile protoplasts require shorter exposure times. Repeat experiments over several consecutive days, with continual observation and adjustment. Somatic hybridization is a "numbers game"; therefore, generate a large number of fusion cultures for each attempted parental combination.

\section{Protoplast culture}

Culture protoplasts in a manner that maximizes gas exchange (thinlayered, semisolid media or shallow liquid media). Seal fusion cultures tightly with Nescofilm (Karlan Chemical Corp., Torrance, Calif.) or other appropriate film to avoid desiccation; media containing mannitol are particularly susceptible to desiccation. Maintain high humidity during culture and osmoticum reduction.

For Citrus, I have observed that extremely high plating efficiencies can inhibit the induction of somatic embryogenesis and subsequent plant regeneration. If high plating efficiencies are observed early during the culture cycle (first 4-8 weeks), dilute the culture or transfer cultures to solid medium early (Grosser and Gmitter, 1990a). Transfer callus or somatic embryos recovered following protoplast culture regularly and do not leave them on the same medium-plates for more than 4 weeks. Somatic embryos (including those with distorted shapes) that do not yield plants following several passages on germination media can sometimes be induced to regenerate plants via adventive shoot-bud induction upon transfer to cytokinin-containing media (Grosser and Gmitter, 1990a). In most cases, plants can eventually be recovered from semi-organized green tissue.

Establish efficient plant regeneration from protoplasts for at least one parent in each desired combination before attempting somatic hybridization. In my opinion, sophisticated somatic hybrid selection schemes have been over-emphasized, often at the expense of plant regeneration. The use of metabolic inhibitors, irradiation, deficient mutants, protoplast labeling, and flow cytometry, or micromanipulation may often be avoided by achieving efficient protoplast fusion and plant regeneration. In Citrus, somatic hybrid combinations are generally competitive, and somatic hybrid plants can be recovered even when populations of regenerated plants consist primarily of parental types from unfused protoplasts (Tusa et al., 1990).

\section{Literature Cited}

Chand, P.K., M.R. Davey, J.B. Power, and E.C. Cocking. 1988. An improved procedure for protoplast fusion using polyethylene glycol. J. Plant Physiol. 133:480-485.

Gmitter, F.G., Jr., J.W. Grosser, and G.A. Moore. 1992. Citrus, p. 335-370. In: R.E. Litz and F. Hammerschlag (eds.). Biotechnology of perennial fruit crops. CAB International, Oxon, U.K.

Grosser, J.W. 1994. In vitro culture of tropical fruits, p. 475-496. In: I.K. Vasil and T.A. Thorpe (eds.). Plant cell and tissue culture. Kluwer Academic Publishers, Dordrecht, The Netherlands.

Grosser, J.W. and J.L. Chandler. 1987. Aseptic isolation of leaf protoplasts from Citrus, Poncirus, Citrus $\times$ Poncirus hybrids and Severinia for use in somatic hybridization experiments. Scientia Hort. 31:253-257.

Grosser, J.W. and G.B. Collins. 1984. Isolation and culture of Trifolium rubens protoplasts with whole plant regeneration. Plant Sci. Lett. 37:165-170.

Grosser, J.W. and F.G. Gmitter, Jr. 1990a. Protoplast fusion and citrus improvement. Plant Breeding Rev. 8:339-374.

Grosser, J.W. and F.G. Gmitter, Jr. 1990b. Wide hybridization of Citrus via protoplast fusion: Progress, strategies and limitations, p. 31-41. In: A.B. Bennett and S.D. O'Neill (eds.). Horticultural biotechnology. Plant biology II. Wiley-Liss, New York.

Harms, C.T. and I. Potrykus. 1978. Fractionation of plant protoplasts types by iso-osmotic density gradient centrifugation. Theor. Applied Genet. 53:5763.

Kao, K.N. and M.R. Michayluk. 1975. Nutritional requirements for growth of Vicia hajastana cells and protoplasts at a very low population density in liquid media. Planta 126:105-110.

Kobayashi, S., H. Uchimaya, and I. Ikeda. 1983. Plant regeneration from 'Trovita' orange protoplasts. Jpn. J. Breeding 33:119-122.

Menczel, L., F. Nagy, Z. Kiss, and P. Maliga. 1981. Streptomycin resistant and sensitive hybrids of Nicotiana tabacum and Nicotiana knightiana: Correlation of resistance with N. tabacum plastids. Theor. Applied Genet. 53:5763.

Myers, J.R., J.W. Grosser, N.L. Taylor, and G.B. Collins. 1989. Genotype dependent whole plant regeneration from protoplasts of red clover (Trifolium pratense L.). Plant, Cell, Tissue Organ Culture 19:113-127.

Ohgawara, T., S. Kobayashi, E. Ohgawara, H. Uchimaya, and S. Ishu. 1985. Somatic hybrid plants obtained by protoplast fusion between Citrus sinensis and Poncirus trifoliata. Theor. Applied Genet. 71:1-4.

Russell, J.A. and B.H. McCown. 1986. Culture and regeneration of Populus leaf protoplasts isolated from non-seedling tissue. Plant Sci. 46:133-142. 
Tusa, N., J.W. Grosser, and F.G. Gmitter, Jr. 1990. Plant regeneration of 'Valencia' sweet orange, 'Femminello' lemon, and the interspecific somatic hybrid following protoplast fusion. J. Amer. Soc. Hort. Sci. 115:10431046.

Vardi, A., P. Arzee-Gonen, A. Frydman-Shani, and S. Bleichman. 1989. Protoplast fusion mediated transfer of organelles from Microcitrus and Citrus and regeneration of novel alloplasmic trees. Theor. Applied Genet. 78:741-747.
Vardi, A., A. Breiman, and E. Galun. 1987. Citrus cybrids: Production by donor-recipient protoplast-fusion and verification by mitochondrial-DNA restriction profiles. Theor. Applied Genet. 75:51-58.

Vardi, A. and E. Galun. 1988. Recent advances in protoplast culture of horticultural crops: Citrus. Scientia Hort. 37:217-230.

Vardi, A., P. Spiegel-Roy, and E. Galun. 1982. Plant regeneration from Citrus protoplasts: Variability in methodological requirements among cultivars and species. Theor. Applied Genet. 62:171-176.

\title{
A Review of Plant Embryo Culture
}

\author{
Mark P. Bridgen \\ Department of Plant Science, U-67, 1376 Storrs Road, University of Connecticut, Storrs, CT 06269
}

Tapping germplasm resources to improve cultivated plants depends on introducing natural variability through traditional and biotechnological breeding methods. Intervarietal and interspecific crosses, followed by selection, have accounted for the improvement in quality and yield potential of practically all major crops (Raghavan, 1986). One biotechnological technique that has been beneficial is embryo culture.

Embryo culture involves isolating and growing an immature or mature zygotic embryo under sterile conditions on an aseptic nutrient medium with the goal of obtaining a viable plant. The basic premise for this technique is that the integrity of the hybrid genome is retained in a developmentally arrested or an abortive embryo and that its potential to resume normal growth may be realized if supplied with the proper growth substances. The technique depends on isolating the embryo without injury, formulating a suitable nutrient medium, and inducing continued embryogenic growth and seedling formation.

The culture of immature embryos is used to rescue embryos that would normally abort or that would not undergo the progressive sequence of ontogeny. This process is difficult due to the tedious dissection necessary and the complex nutrient medium requirements. Success with this type of culture depends strongly on the developmental stage of the embryo when it is isolated (Monnier, 1978; Raghavan, 1980).

The culture of mature embryos from ripened seeds is used to eliminate seed germination inhibitors or to shorten the breeding cycle if, for example, dormancy is a problem. This culture is easy and only requires a simple nutrient medium with agar, sugar, and minerals.

\section{HISTORY}

Embryo culture, sometimes called embryo rescue, is an in vitro technique that has been used for more than half a century to save the hybrid products of fertilization when they might otherwise degenerate. Success was first achieved in 1904 by Hannig who obtained viable plants from mature embryos of two crucifers that were isolated aseptically and grown on a mineral salt medium supplemented with sugar (Norstog, 1979). In 1924, Dietrich cultured mature and immature embryos of various plant species to determine whether they could still germinate without completing the dormancy period. He reported that the mature embryos grew immediately, circumventing dormancy. The immature embryos germinated precociously without further embryo development. Laibach first described zygotic embryo culture for interspecific hybridization in 1925 . He observed that seeds from interspecific crosses between Linum perenne L. x Linum austriacum L. were nonviable; however, if embryos were excised early during seed development and cultured in vitro, then embryo abortion was overcome. Later, van Overbeek et al. (1941) discovered that small Datura hybrid embryos could be grown in culture on media containing

Storrs Agricultural Experiment Station no. 1503. The cost of publishing this paper was defrayed in part by the payment of page charges. Under postal regulations, this paper therefore must be hereby marked advertisement solely to indicate this fact. coconut milk. This discovery ultimately led to understanding the importance of reduced $\mathrm{N}$ in the form of amino acids for embryo culture.

Since the early 1940s, embryo culture has been used increasingly to understand the physical and nutritional requirements for embryonic development, bypass seed dormancy, shorten the breeding cycle, test seed viability, provide material for micropropagation, and rescue immature hybrid embryos from incompatible crosses (Hu and Wang, 1986).

\section{APPLICATIONS}

Embryo culture is one of the earliest forms of in vitro culture applied to practical problems and is probably the tissue culture technique that has proven of greatest value to breeders (Dunwell, 1986). Its major application in plant breeding has been for interspecific hybridization.

Many unsuccessful crosses result from embryo abortion. Early embryo abortion occurs primarily because the endosperm fails to develop properly (Hu and Wang, 1986). With interspecific crosses, intergeneric crosses, and crosses between diploids and tetraploids, the endosperm often develops poorly or not at all. By aseptically culturing the embryo in a nutrient medium, this problem may be overcome. Embryos of some nonviable hybrids may possess the potential for initiating development by avoiding postzygotic barriers within the mother plant. Several successful cases have been documented with embryos arising from interspecific hybrids and intergeneric hybrids (Ramming, 1990; Sharma and Gill, 1983; Williams, 1980; Williams and De Lautour, 1980; Williams et al., 1982).

Embryo culture can shorten the breeding cycle by overcoming dormancy in seeds. Dormancy may be caused by endogenous inhibitors, light requirements, low temperatures, dry storage requirements, and embryo immaturity (Yeung et al., 1981). Seed dormancy factors may be localized in the seedcoat, the endosperm, or both. By removing the embryos from the influences of these factors, the embryos germinate and grow quickly and the breeding cycle is shortened. Isolated embryos can also be vernalized and may, in some instances, reduce the generation time by 40 days (Sharma and Gill, 1983).

In addition to the applied uses of embryo culture, the procedure is useful in basic studies. Growing embryos outside the ovule (ex ovulo) is an excellent way to study the nutrition and metabolism of the embryos at various stages of development. The technique can also be used to examine the growth requirements of embryos, the effects of phytohormones and environmental conditions on zygotic embryogenesis, and the regeneration potentials of whole embryos and their segments (Yeung et al., 1981). Embryo culture can be used to localize sites of germination promoters and inhibitors, for studies of embryogenesis, and for cryopreservation (Grout, 1986).

Embryo culture can be used to produce haploids through eliminating chromosomes following distant hybridization. This can occur by rescuing haploid maternal embryos in which the paternal chromosomes have been eliminated. In these situations, fertilization occurs, but the pollen parent chromosomes are subsequently eliminated by the 
seed parent. The viability of the haploid embryo can only be achieved through embryo culture. Chromosome doubling of the rescued embryo produces a homozygote monoploid.

Embryo culture can be used to propagate plants vegetatively. Embryos from genera that have both juvenile and adult characteristics are used as starting material for vegetative propagation. Embryos are responsive because they are juvenile. With the Poaceae, organogenesis occurs easily from juvenile callus tissue. Conifer propagation via immature calli derived from young embryos and axillary shoot formation is also easy. A major problem with this technique, however, is that clones are not produced from the zygotic material unless the embryos have developed from nucellar tissue, as in many types of Citrus.

Embryo culture can be used to study precocious germination, the germination of embryos before the completion of normal embryo development. Usually, precocious germination causes the formation of weak seedlings. To understand the factors that regulate the orderly development of embryos in nature, embryos can be cultured under various conditions to determine what simulates embryological development. Precocious germination occurs because inhibitors are lost when the testa is removed or because the negative osmotic potential is a higher value in vivo. Precocious germination has been prevented in Prunus through ovule culture, where the integument acts as a natural inhibitor (Ramming, 1985).

Embryo culture has been very useful in determining seed viability. This use arose out of early findings that there was a good correlation between the growth of excised embryos of non-after-ripened peach [Prunus persica (L.) Batsch.] seeds and germination of the afterripened seeds (Tukey, 1944). Embryo culture allows the rapid testing of seed viability when seed dormancy can be circumvented.

\section{TECHNIQUES}

In most situations, embryos are located in the sterile environment of the ovule and surface sterilization of embryos is not necessary. Instead, entire ovules or ovaries are surface-sterilized and then embryos are removed aseptically from the surrounding tissues. Since the embryo is often well-protected by surrounding tissues, harsh procedures may be used in surface disinfection. Thus, axenic cultures of embryos are often easily established. Direct disinfection of embryos is needed if seedcoats are cracked or if endophytic pathogens exist inside the seedcoats, as with fescue (Festuca spp.L.), corn (Zea mays L.), and dogwood (Cornus spp. L.) seeds.

The dissection of the embryos can produce problems. Large embryos are not difficult to excise. However, small embryos require the use of microdissecting tools and a dissecting microscope to excise without injury. Embryos are easily damaged when the seedcoat is cut; it is also important that the excised embryo does not become desiccated during culture (Rangan, 1984).

The process of excising immature embryos varies with species. However, many times an incision can be made at the micropylar end of the young ovule and pressure applied at the opposite end to force the embryo out through the opening. If liquid endosperm surrounds the embryo, the pressure it exerts may injure the fragile embryonic tissue if caution is not exercised. When heart-stage and younger embryos are excised, it is important to keep the suspensors intact (Hu and Wang, 1986).

\section{REQUIREMENTS FOR SUCCESS}

Successful development of an embryo depends on many factors. As with most other processes, the plant genotype greatly influences success. Embryos of some species are easier to grow in culture than are others, and differences sometimes occur between closely related cultivars (Collins and Grosser, 1984; Rangan, 1984).

As already indicated, small embryos are difficult to grow in vitro. Specialized techniques can be used to improve success. The use of "nurse" endosperm involves inserting a hybrid embryo into an endosperm dissected from a normally developing, self-pollinated ovule from one of the parents or a third species. The embryo and endosperm are transferred together to the surface of the culture medium (Williams et al., 1982). Modified versions of the nurse endosperm, such as embryo implantation or transplantation, have been adapted to other species (Williams, 1980; Williams and De Lautour, 1980). By using embryo rescue, one can achieve a $30 \%$ to $40 \%$ success rate with intergeneric crosses compared to a $1 \%$ success rate when embryonurse endosperm transplants are not used.

Small or young embryos that abort at early stages of development are often difficult to isolate. The nutritional requirements of young embryos vary greatly and the chances of damaging the embryos are great. In such situations, it may be possible to rescue embryos by ovary or ovule culture methods (Rangan, 1984). Ovaries are excised after pollination and the calyx, corolla, and stamens are removed. The ovary is surface-sterilized and cultured with the cut end of the pedicel inserted into the nutrient medium. If all goes well, the ovary then develops into a fruit with fully developed seeds. For ovule culture, the sterilized ovary is opened and the fertilized ovules are scooped out and transferred to the surface of the culture medium. The reasons for the successful recovery of hybrids from ovary or ovule culture rather than through embryo culture are probably related to nutritional and physical factors and protection of the embryo by the maternal or sporophytic tissues.

Light and temperature are two environmental factors that are of major concern in embryo culture. Embryos sometimes grow best when maintained in darkness for the first 1 to 2 weeks of culture and then transferred to light to allow chlorophyll formation. Isolated embryos frequently germinate in a wider temperature range than intact seeds. The optimum temperature depends on plant species, but normally a high range of 25 to 30C is used (Narayanaswamy and Norstog, 1964). Some embryos, from species such as Lilium, require a lower temperature, i.e., $17 \mathrm{C}$, and others require a cold treatment of $4 \mathrm{C}$ to break dormancy (Pierik, 1987).

The growth conditions of the mother plant are also a consideration in embryo culture. The endosperm and the cotyledons will develop more if the mother plant is grown under well-controlled conditions; embryo growth will consequently be promoted.

\section{MEDIA}

Dieterich (1924) showed that mature embryos could grow normally on a semisolid medium containing only Knop's mineral salts and $2.5 \%$ to $5 \%$ sucrose. However, many scientists believe that the most important aspect of embryo culture is medium selection. Several formulations of mineral salts have been used for embryo culture without much critical evaluation of the role of individual elements (Bhojwani and Razdan, 1983). Murashige and Skoog (1962) and Gamborg's B5 medium (Gamborg et al., 1968), with certain degrees of modification, are the most widely used basal media in embryo culture.

The exact nutritional requirement depends on the stage of embryo development. Raghavan (1966) identified two phases of embryo development. In the heterotrophic phase, the young embryo depends on the endosperm and the surrounding maternal tissues, and requires a more complex medium and higher osmotic pressure than older embryos. The continued development of young embryos requires complex media supplemented with combinations of vitamins, amino acids, growth hormones, and, in some cases, natural extracts, such as tomato juice and coconut milk, to support development.

During the autotrophic phase, the second stage of embryo growth, the embryo is metabolically capable of synthesizing substances required for its growth from the salts and sugar. In this phase, embryos can germinate and grow on a simple inorganic medium supplemented with a carbon source, such as sucrose.

Ammonium nitrate and potassium nitrate are the most frequently used sources of inorganic $\mathrm{N}$ in embryo culture. Ammonium in the medium is essential or preferential for proper growth and differentiation of immature embryos (Matsubara, 1964; Umbeck and Norstog, 1979). Ammonium usually is combined with an organic acid, particularly with malate or citrate anions. Among various amino acids, glutamine and asparagine are the most effective (Sanders and Burkholder, 1948). Casein hydrolysate is a complex mixture of amino acids and is commonly used in embryo culture media to stimulate growth. Vitamins, such as biotin, thiamine, pantothenic acid, nicotinic 
acid, ascorbic acid, inositol, and pyroxidine, are commonly added, but have not been proven to be essential.

Adding amino acids to the culture medium may stimulate embryo growth (Bhojwani and Razdan, 1983). Glutamine is the most effective amino acid for cultured embryo growth (Monnier, 1978). Asparagine may also enhance embryo growth (Hannig, 1904), but it can be inhibitory (Matsubara, 1964). Casein hydrolysate is a complex mixture of 18 amino acids that has been widely used as an additive to embryo culture media. When added alone to a medium, none of the amino acids match the beneficial effect of casein hydrolysate (Sanders and Burkholder, 1948). However, work with the induction and maturation of somatic embryos demonstrates that amino acids such as proline, serine, and glutamine can replace casein hydrolysate.

The landmark work of van Overbeek et al. (1942) demonstrated that embryos younger than the post-torpedo stage could be cultured by adding the liquid endosperm of coconut to the culture medium. By modifying a medium to mimic the endosperm that surrounds immature embryos in the ovule, success was obtained where it had not been possible previously. The growth-promoting factor in the coconut milk was referred to as "embryo factor." By using coconut milk in media for young embryos, precocious germination can be avoided. Other natural substances, such as skim milk, dried brewer's yeast (malt extract), casein hydrolysate, and diffusates from the seeds of several plant species, can substitute for coconut milk, depending on the species under investigation (Bhojwani and Razdan, 1983). Although synthetic media are used, these natural plant extracts are still suitable amino acid sources for culturing immature embryos. A purely synthetic medium can be developed to substitute for coconut milk by enriching White's (1934) medium with phosphate and fortifying with glutamine, alanine, and five other amino acids (Cameron-Mills and Duffus, 1977).

Sucrose is the most commonly used C energy source for embryo culture. Sucrose is primarily an energy source, although it also plays an important role in maintaining suitable osmotic potential of nutrient media. Mature embryos are usually grown on media with $2 \%$ to $3 \%$ sucrose, whereas immature embryos grow better at $8 \%$ to $12 \%$, which mimic the high osmotic potential within the young embryo sac. Generally, the younger the excised embryo, the higher the medium osmolarity required. Raghavan $(1977,1980)$ believes that this high osmolarity prevents precocious germination and keeps cells that are in a state of division from going into a state of elongation.

Agar is the most commonly used agent to solidify culture media. Concentrations of $0.5 \%$ to $1.5 \%$ are generally used for embryo culture (Hu and Wang, 1986). High concentrations of agar may inhibit growth due to reduced water availability, quality of agar, or contaminating salts.

Plant growth regulators generally play a small role in embryo culture. Exogenous auxins do not seem to be required for plant embryo growth in vitro (Norstog, 1979). This observation supports reports that somatic embryo induction is inhibited by high concentrations of exogenous auxin in the medium and stimulated by low concentrations or in its absence. Cytokinins, when used as the sole hormone, are ineffective or only slightly promote young embryo growth. However, they promote growth and differentiation of embryos when they are combined with some auxins (Veen, 1963). Monnier (1978) suggests that hormones should not be added to embryo culture media as they cause structural abnormalities. Auxins and cytokinins are not generally used for embryo culture unless callus induction is needed. Gibberellins sometimes stimulate precocious germination or are used to overcome dormancy.

\section{CONCLUSION}

Embryo culture is a valuable in vitro tool for breeding. It is most often used to rescue embryos from interspecific and intergeneric crosses and from embryos that do not fully develop naturally (as in early ripening and seedless fruit where the embryo aborts). The method also can be used to rescue seedless triploid embryos, produce haploids, overcome seed dormancy, or determine seed viability. It is useful in understanding embryo morphogenesis and precocious germination. As research continues with this technique, new and valuable uses will be developed to assist the biotechnological breeding of plants.

\section{Literature Cited}

Bhojwani, S.S. and M.K. Razdan. 1983. Plant tissue culture: Theory and practice. Elsevier, Amsterdam.

Cameron-Mills, V. and C.M. Duffus. 1977. The in vitro culture of immature barley embryos on different culture media. Ann. Bot. 41:1117-1127.

Collins, G.B. and J.W. Grosser. 1984. Culture of embryos, p. 241-257. In: I.K. Vasil (ed.). Cell culture and somatic cell genetics of plants. vol. 1. Laboratory procedures and their applications. Academic, New York.

Dietrich, K. 1924. Über Kultur von Embryonen ausserhalb des Samens. Flora (Jena) 117:379-417.

Dunwell, J.M. 1986. Pollen, ovule and embryo culture as tools in plant breeding, p. 375-404. In: L.A. Withers and P.G. Alderson (eds.). Plant tissue culture and its agricultural applications. Butterworths, London.

Gamborg, O.L., R.A. Miller, and K. Ojima. 1968. Nutrient requirements of suspension cultures of soybean root cells. Expt. Cell Res. 50:151-158.

Grout, B.W.W. 1986. Embryo culture and cryopreservation for the conservation of genetic resources of species with recalcitrant seed, p. 303-309. In: L.A. Withers and P.G. Alderson (eds.). Plant tissue culture and its agricultural applications. Butterworths, London.

Hannig, E. 1904. Zur Physiologie pflanzlicher Embryonen. I. Über die Kultur von Cruciferen-embryonen ausserhalb des Embryosacks. Bot. Ztg. 62:4580.

Hu, C. and P. Wang. 1986. Embryo culture: Technique and applications, p. $43-$ 96. In: D.A. Evans, W.R. Sharp, and P.V. Ammirato (eds.). Handbook of plant cell culture. vol. 4. Macmillan, New York.

Laibach, F. 1925. Das Taubwerden von Bastardsamen und die künstliche Aufzucht früh absterbender Bastardembryonen. Z. Bot. 17:417-459.

Matsubara, S. 1964. Effect of nitrogen compounds on the growth of isolated young embryos of Datura. Bot. Mag. (Tokyo) 77:253-259.

Monnier, M. 1978. Culture of zygotic embryos, p. 277-286. In: T.A. Thorpe (ed.). Frontiers of plant tissue culture 1978. Univ. of Calgary Press, Canada.

Murashige, T. and F. Skoog. 1962. A revised medium for rapid growth and bioassays with tobacco tissue cultures. Physiol. Plant. 15:473-497.

Narayanaswamy, S. and K. Norstog. 1964. Plant embryo culture. Bot. Rev. 30:587-628.

Norstog, K. 1979. Embryo culture as a tool in the study of comparative and developmental morphology, p. 179-202. In: W.R. Sharp, P.O. Larsen, E.F. Paddock, and V. Raghavan (eds.). Plant cell and tissue culture. Ohio State Univ. Press, Columbus.

Pierik, R.L.M. 1987. In vitro culture of higher plants. Martinus Nijhoff, Dordrecht, Netherlands.

Raghavan, V. 1966. Nutrition, growth and morphogenesis of plant embryos. Biol. Rev. 41:1-58.

Raghavan, V. 1977. Applied aspects of embryo culture, p. 375-397. In: J. Reinert and Y.P.S. Bajaj (eds.). Applied and fundamental aspects of plant cell, tissue, and organ culture. Springer-Verlag, Berlin.

Raghavan, V. 1980. Embryo culture, p. 209-240. In: I.K. Vasil (ed.). Perspectives in plant cell and tissue culture. Intl. Rev. Cytol., Suppl. 11B. Academic, New York.

Raghavan, V. 1986. Embryogenesis in angiosperms. Cambridge Univ. Press, Cambridge, U.K.

Ramming, D.W. 1985. In ovulo embryo culture of early-maturing Prunus. HortScience 20:419-420.

Ramming, D.W. 1990. The use of embryo culture in fruit breeding. HortScience 25:393-398.

Rangan, T.S. 1984. Culture of ovules, p. 227-231. In: I.K. Vasil (ed.). Cell culture and somatic cell genetics of plants. vol. 1. Laboratory procedures and their applications. Academic, New York.

Sanders, M.E. and P.R. Burkholder. 1948. Influence of amino acids on growth of Datura embryos in culture. Proc. Natl. Acad. Sci. USA 34:516526.

Sharma, H.C. and B.S. Gill. 1983. New hybrids between Agropyron and wheat. 2. Production, morphology and cytogenetic analysis of $F_{1}$ hybrids and backcross derivatives. Theor. Appl. Genet. 66:111-121.

Tukey, H.B. 1944. Excised-embryo method of testing the germinability of fruit seed with particular reference to peach seed. Proc. Amer. Soc. Hort. Sci. 45:211-219.

Umbeck, P.F. and K. Norstog. 1979. Effects of abscisic acid and ammonium ion on morphogenesis of cultured barley embryos. Bul. Torrey Bot. Club 106:110-116.

van Overbeek, J., M.E. Conklin, and A.F. Blakeslee. 1941. Factors in coconut milk essential for growth and development of very young Datura embryos. Science 94:350-351. 


\section{WORKSHOP}

van Overbeek, J., M.E. Conklin, and A.F. Blakeslee. 1942. Cultivation in vitro of small Datura embryos. Amer. J. Bot. 29:472-477.

Veen, H. 1963. The effect of various growth-regulators on embryos of Capsella bursapastoris growing in vitro. Acta Bot. Neerl. 12:129-171.

White, P.R. 1934. Potentially unlimited growth of excised tomato root tips in a liquid medium. Plant Physiol. 9:585-600.

Williams, E. 1980. Hybrids between Trifolium ambiguum and T. hybridum obtained with the aid of embryo culture. N.Z. J. Bot. 18:215-220.

Williams, E. and G. De Lautour. 1980. The use of embryo culture with transplanted nurse endosperm for the production of interspecific hybrids in pasture legumes. Bot. Gaz. (Chicago) 141:252-257.

Williams, E.G., I.M. Verry, and W.M. Williams. 1982. Use of embryo culture in interspecific hybridization, p. 119-128. In: I.K. Vasil, W.R. Scowcroft, and K.J. Frey (eds.). Plant improvement and somatic cell genetics. Academic, New York.

Yeung, E.C., T.A. Thorpe, and C.J. Jensen. 1981. In vitro fertilization and embryo culture, p. 253-271. In: T.A. Thorpe (ed.). Plant tissue culture: Methods and applications in agriculture. Academic, New York. 